\title{
JARDINS DE FORA E DENTRO: NOVOS MÓVEIS EM OITOCENTOS GARDENS OUT AND INSIDE: NEW FURNITURE IN 19TH CENTURY
}

\author{
Alexandre Tojal* \\ Instituto de História da Arte/ FCSH/ \\ Universidade Nova de Lisboa
}

\section{Resumo}

No contexto de um estudo de doutoramento em curso, dedicado aos jardins domésticos oitocentistas, o mobiliário específico surge como território de investigação estimulante, a suscitar a construção de um conhecimento discursivo autónomo.

$\mathrm{O}$ incremento dos jardins domésticos atinge valores significantes em Lisboa desde o dobrar de Oitocentos. Mas a sedução dos jardins não se confina ao exterior; plantas e flores invadem a paisagem interior da casa sob várias intensidades. Jardins de Inverno, salas, varandas e espaços de transição são contaminados por um mundo vegetal que reclama novos móveis. Vasos de ferro fundido, de louça branca, do Japão ou de Ruão, jardineiras, mesas, aquários, cadeiras de vime ou de bambu, baloiços e canapés são alguns dos elementos compositivos destas paisagens oitocentistas, exteriores ou interiores à casa. À luz dos valores da cultura e sociabilidade oitocentistas, propomo-nos abordar tipologias de móveis, formas de produção e comercialização e instrumentos de difusão e generalização.

Palavras-chave: móveis de jardim, móveis de ferro, jardins domésticos, século XIX.

\section{Abstract}

In the context of a doctoral study, focused in the nineteenth century domestic gardens, the specific furniture emerges as a challenging research area, raising an autonomous discursive knowledge.

The increase of domestic gardens reaches significant values in Lisbon since the mid of the 1800's. However the seduction by gardens is not confined to the exterior; plants and flowers invade the interior landscape under diferent intensities. Winter gardens, rooms, parlours, verandas and transitional areas are contaminated by a vegetal world wich claims for new furniture. Cast iron pots, white earthenware pots, Japan pots, Rouen pots, jardinieres, tables, aquariums, wicker and bamboo chairs, swings and benches are some of the compositional

*E-mail: aamtojal@gmail.com 
elements of those exteriors or interiors landscapes. Based on nineteenth century sociability and culture values, we propose to adress furniture typologies, forms of production and trade, promoting and dissemination tools.

Keywords: garden furniture, iron furniture, domestic gardens, nineteenth century

No contexto de um estudo de doutoramento em curso $^{1}$, dedicado aos jardins domésticos oitocentistas, o mobiliário para os jardins surge, desde logo na fase heurística, como território de investigação possível, a suscitar a construção de um conhecimento discursivo autónomo.

$\mathrm{O}$ incremento dos jardins domésticos atinge valores significantes em Lisboa desde a primeira metade de Oitocentos. O programa da arquitectura doméstica erudita fazia-se acompanhar há muito de um equiparado programa de jardim. Sobrevivem exemplares em Portugal desde o século XVI, ainda hoje visitáveis, mas esta prática tem seguramente raízes muito mais remotas, anteriores à própria fundação da nacionalidade. O tempo da inculturação romana terá feito, também neste campo, marcas fortes, ao trazer o jardim para a organização do espaço doméstico.

No século XIX, e em Lisboa concretamente, ocorre um movimento obreiro, espelhado em empreitadas de construção, renovação ou ampliação, coerente com uma política de aformoseamento promovida pela Câmara Municipal de Lisboa. Inúmeras casas unifamiliares e prédios de rendimento, ainda hoje sobreviventes, apresentam uma simetria de vãos e regularidade de fachada em total consonância com aquela política municipal, prosseguida durante a primeira metade do século XIX, e mais intensamente no segundo quartel ${ }^{2}$. O poder regulador espelhado nos inúmeros pareceres redigidos pelo técnico responsável ${ }^{3}$, o arquitecto Malaquias Ferreira Leal (1787?-1859), mediante requerimentos dos munícipes, prescreve para as preexistências construtivas vernaculares a lição da arquitetura erudita, dando ao normal prédio de habitação ou rendimento uma coerência no tecido urbano e uma estética mais cuidada.

Da Graça a Alfama, Mouraria, Anjos, São José, Bairro Alto, Príncipe Real, Rato, São Bento, Santos, Lapa ou Santa Isabel, encontramos - ainda hoje viva na cidade - uma arquitectura de traço popular, que nesse segundo quartel se redesenha, conquistando: simetria, conseguida na distribuição equilibrada dos vãos; altura, nos andares acrescentados; novidade, nas platibandas cegas ou vazadas, nas varandas corridas protegidas e decoradas com grades de ferro que se desmultiplicam nas janelas de sacada.

Os jardins domésticos não se desligam desta dinâmica oitocentista da cidade. Da lição erudita dos grandes palácios, na sua maioria construídos antes do século XIX, continua a fazer parte o jardim (Fig. 1). Este pode manter-se fiel a um programa originário, setecentista, de feição classicizante, pode, ao invés, 
apresentar-se renovado, à inglesa, entendido como gosto moderno, ou pode ainda espelhar uma interessante fusão daquelas duas gramáticas, espelhando uma outra síntese do romantismo português.

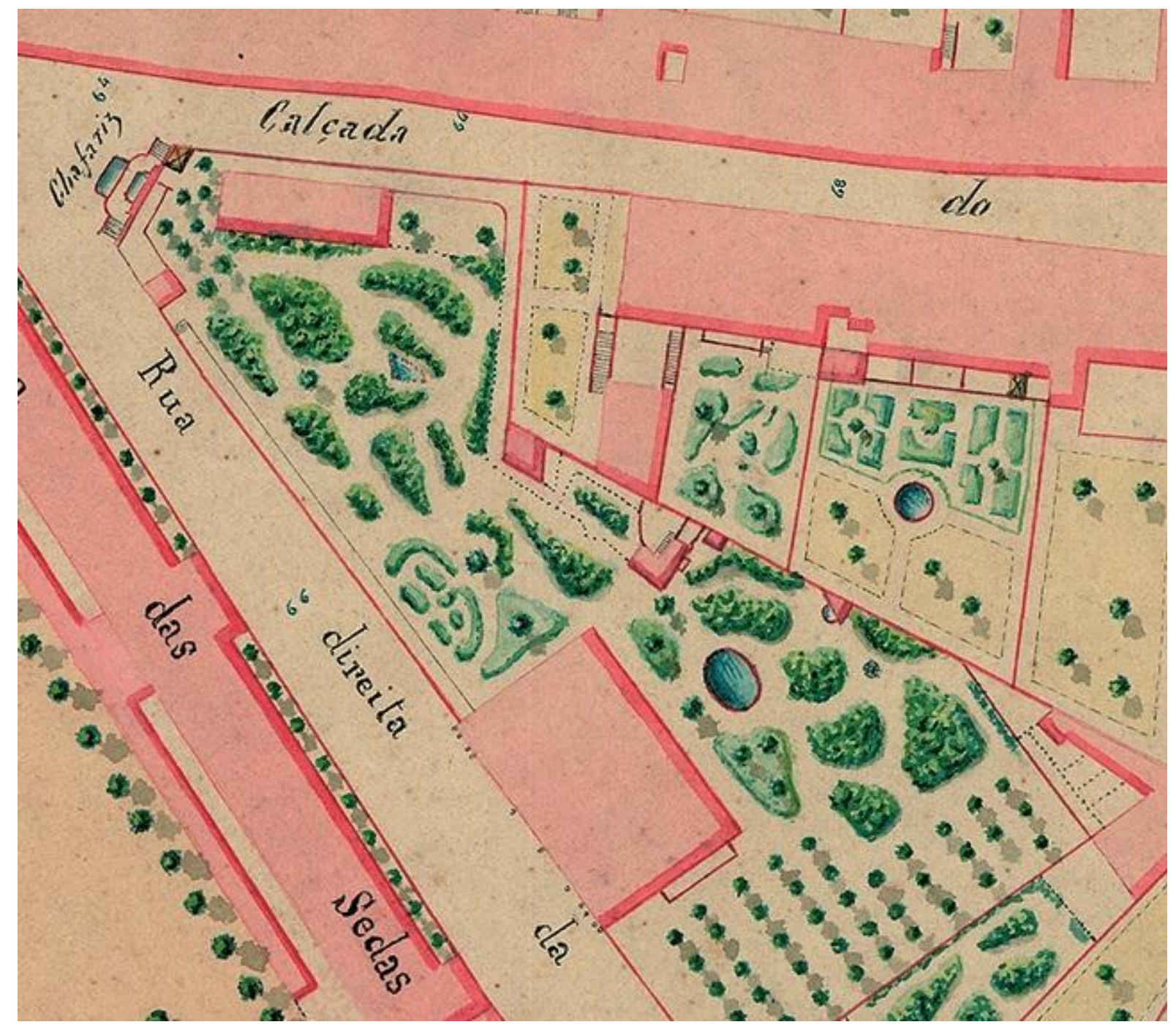

Fig. 1. Jardim do palácio Palmela, ao Rato, Lisboa. Levantamento Filipe Folque (1856-1858), Instituto Geográfico Português, pl. 26, pormenor

Concretizações significantes de arte da paisagem, representadas com enorme evidência nos documentos cartográficos, os jardins espelham soluções estéticas, formais e compositivas que falam do seu tempo, da cultura e da sociabilidade oitocentistas. Evocam a presença da modernidade no desenho e na procura de espécies novas que os povoam, mas também do conservadorismo na permanência de práticas resistentes à moda; dão conta da curiosidade e inventiva na pesquisa de novas flores, por vezes requintadas, por vezes extravagantes, ou na recorrência de habitats distantes aclimatados progressivamente, com técnicas cada vez mais aperfeiçoadas e bem-sucedidas, criando no meio urbano novos idílios naturais; recriam universos tropicais frequentemente encapsulados em arquitecturas do ferro, trazendo consigo matrizes culturais novas e uma outra 
poética na relação do homem com a natureza; evidenciam a força de um ecletismo natural que familiariza floras exóticas e espécies nacionais. Os jardins evocam uma paisagem pessoal, espelho habitado - nas modas, nos gostos, nos gestos sociais - do seu proprietário, família, amigos.

A sedução dos jardins não se confina ao exterior; plantas e flores invadem a paisagem interior da casa sob várias intensidades. Jardins de Inverno, salas, quartos, varandas e espaços de transição são contaminados por um mundo vegetal que reclama novos móveis.

As plantas ornamentais e as flores tornam-se elementos compositivos indispensáveis ao programa decorativo de Oitocentos. Não há casa medianamente burguesa "que não tenha de portas a dentro uma dúzia de vasos. (...) As varandas transformam-se em caramanchéis, as janelas de peitoril em jardins e os consoles em canteiros. Plantas e flores por toda a parte."4

Que móveis? Com que função? Para o jardim, para a sala ou para ambos os espaços? De que materiais? Onde se compram? Como se divulgam? São questões para as quais proporemos respostas neste texto, longe da pretensão de completude. Desde logo o conceito de móvel afigura-se de difícil delimitação absoluta. Não sendo nós especialistas em História do Mobiliário, assumimos uma operatoriedade mais ampla, privilegiando o maior elenco de peças e a sua relação com a temática dos jardins, no exterior e no interior, em detrimento de uma rígida disciplina conceptual.

A cartografia tornou-se uma fonte imprescindível para o estudo dos jardins ${ }^{5}$, pelo rigor e detalhe com que são representados. Para além do desenho formal com as correspondentes manchas vegetais, reconhecem-se cascatas, canais de água, lagos, tanques, escadas. Já para os móveis a representação cartográfica é omissa, no entanto, os inúmeros jardins reconhecidos não podem deixar de constituir um provável território de expectativas.

Prosseguindo uma heurística orientada, essencialmente a partir da colecção de fotografias mais antigas do Arquivo Fotográfico Municipal de Lisboa; do arquivo da Casa Palmela ${ }^{6}$, família que deu enorme atenção aos jardins das suas casas ao longo de décadas; de publicações periódicas da especialidade, de que é exemplo maior o Jornal de Horticultura Pratica ${ }^{7}$; de fontes literárias, nomeadamente de Eça de Queirós e Ramalho Ortigão, onde o século XIX surge em toda a sua diversidade, seja na ficção seja na ensaística, apontando a pena para os jardins e para as plantas e flores no quotidiano doméstico e social; de bibliografia mais recente sobre História do Mobiliário e dos Interiores, recenseamos um conjunto significativo de móveis, a saber: jardineiras, floreiras, mesas, cadeiras, canapés, bancos, bornes, aquários, baloiços, caixas de plantas para janelas, diferentes géneros de vasos: em barro, em barro pintado, em ferro fundido, em louça branca, do Japão, de Ruão. E muitos materiais concorrem para a execução destes móveis: vime, bambu, ferro, madeira, cortiça, zinco, cerâmica, vidro.

Em Portugal, as exposições oitocentistas - "lugares privilegiados de informação"8 - constituem indicadores importantes do que se fabrica, comercializa e consome. Se para as duas primeiras iniciativas não se encontram notícias relevantes para o nosso objecto (de 1838 e 1840), o mesmo não acontece com a 
terceira exposição industrial, promovida, à semelhança das anteriores, pela Sociedade Promotora da Indústria Nacional, em 1844, no convento dos Paulistas, em Lisboa. Aberta ao público de 8 a 30 de Setembro, a Exposição de Manufacturas Nacionaes contou com 134 produtores e 60.000 visitantes ${ }^{9 !}$

Organizada ao longo de seis salas, logo na primeira surgiam "amostras de manufaturas de ferro coado das fábricas do Porto e d'esta Corte, a saber: (...), canapés para jardins primorosamente adornados com baixos-relevos, em parte vazados, representando uma parreira enlaçada, com suas folhas e cachos: o tecido da palhinha é todo de ferro, e tudo tirado de um só jacto de fundição; vasos para flores adornados de baixos-relevos; (...) figuras, lanças, flores-de-lis, e muitos outros ornatos para grades e portais de ferro."10

Os canapés e vasos em ferro coado introduzem um tópico importante, a tecnologia. O ferro, abundantemente trabalhado na forja, no século XIX, ganha novo fôlego com os progressos recentes conquistados na sua fundição. Poucos anos antes da exposição de Lisboa, de 1844, na Exposition Nationale, de 1839, em Paris, as fundições Calla, Tusey e Val d'Osne, tinham apresentado as grandes potencialidades do ferro fundido: enorme versatilidade na moldagem, e portanto maior qualidade artística, durabilidade, consistência e baixo custo ${ }^{11}$.

À semelhança de outros móveis em ferro que irão ganhar grande difusão por toda a segunda metade de Oitocentos ${ }^{12}$, alimentada por uma produção industrial em série, também os móveis para jardim, quer público, quer privado, ir-se-ão generalizar. Os referidos canapés, mas também cadeiras, bancos, mesas, vasos, o núcleo essencial do mobiliário para jardim, vulgarizar-se-á, sob diferentes modelos, mais simples ou mais elaborados, mais acessíveis ou mais dispendiosos.

Em 1850 encontramos um banco de jardim em ferro fundido desenhado por Malaquias Ferreira Leal, arquitecto municipal. De inspiração goticicizante, com grande probabilidade terá sido ideado para os Passeios Públicos, sob gestão camarária, mas certamente que o modelo poderá ter povoado jardins privados. Tipologia recorrente, este banco - que também poder receber a designação de canapé - será tratado sob várias estéticas, por exemplo, num ecletismo de fim de século, como encontramos em uso num pequeno jardim burguês (Fig. 2). A mesma inspiração do gótico está presente no banco do Passeio Público da Estrela, inaugurado em 1852 (Fig. 3).

A família Palmela compra canapés para a quinta do Lumiar, em Setembro de 1856, numa despesa de $143 \$ 760$ réis, que também inclui jardineiras e cadeiras em ferro ${ }^{13}$. Comprada em 1845 aos herdeiros do marquês de Angeja, o palácio manteve um grande jardim a par da área agrícola, com uma genealogia de responsáveis de peso: inicialmente o horticultor belga Jean Rosenfelder, depois o médico e botânico Frederic Welwisch, seguiu-se, durante várias décadas, o jardineiro Jacob Weiss, substituído, em 1884, por Otto Lauche ${ }^{14}$. 


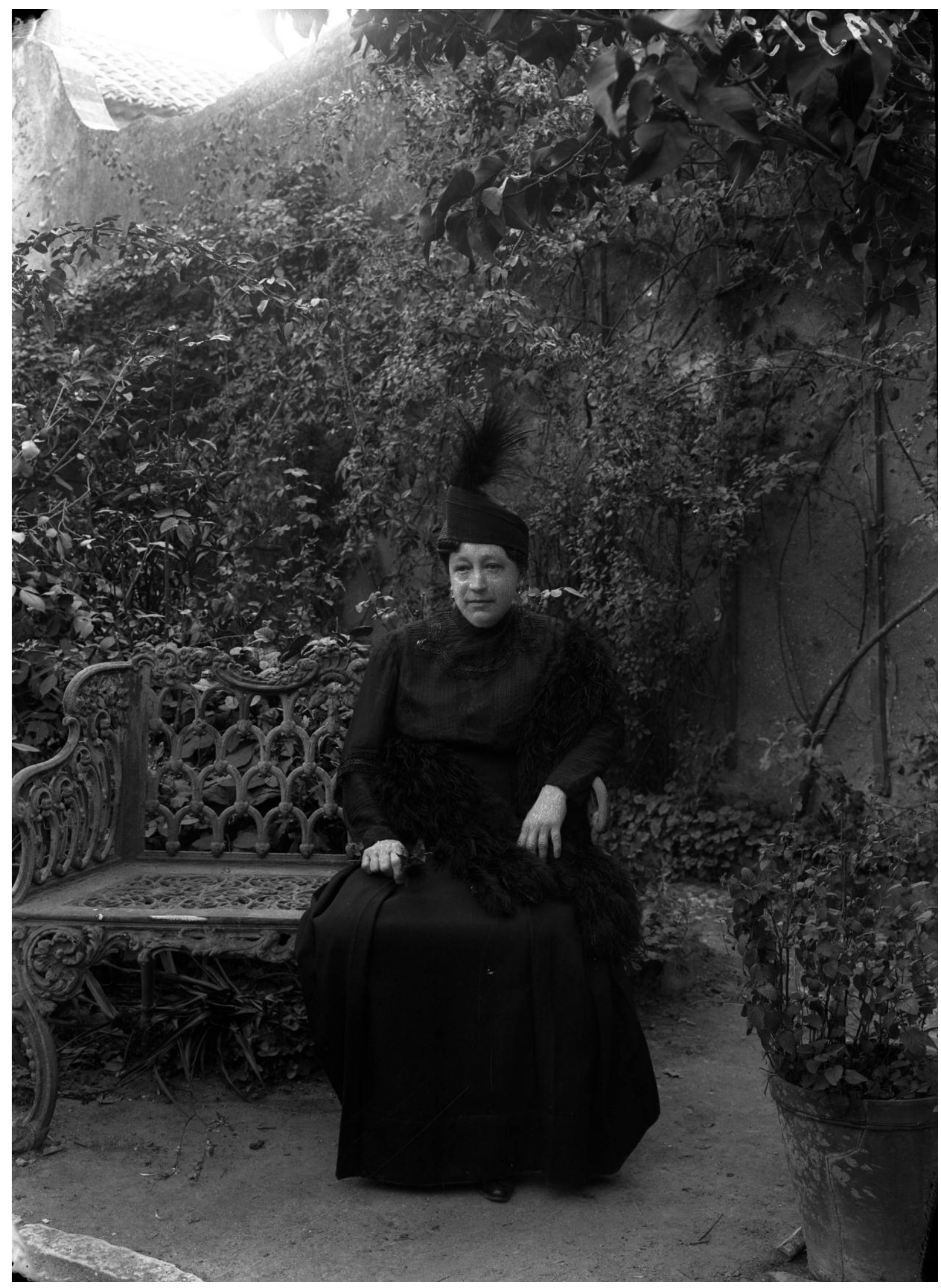

Fig. 2. Banco de ferro fundido num jardim doméstico não identificado. Arquivo Fotográfico Municipal de Lisboa, ACU002301 


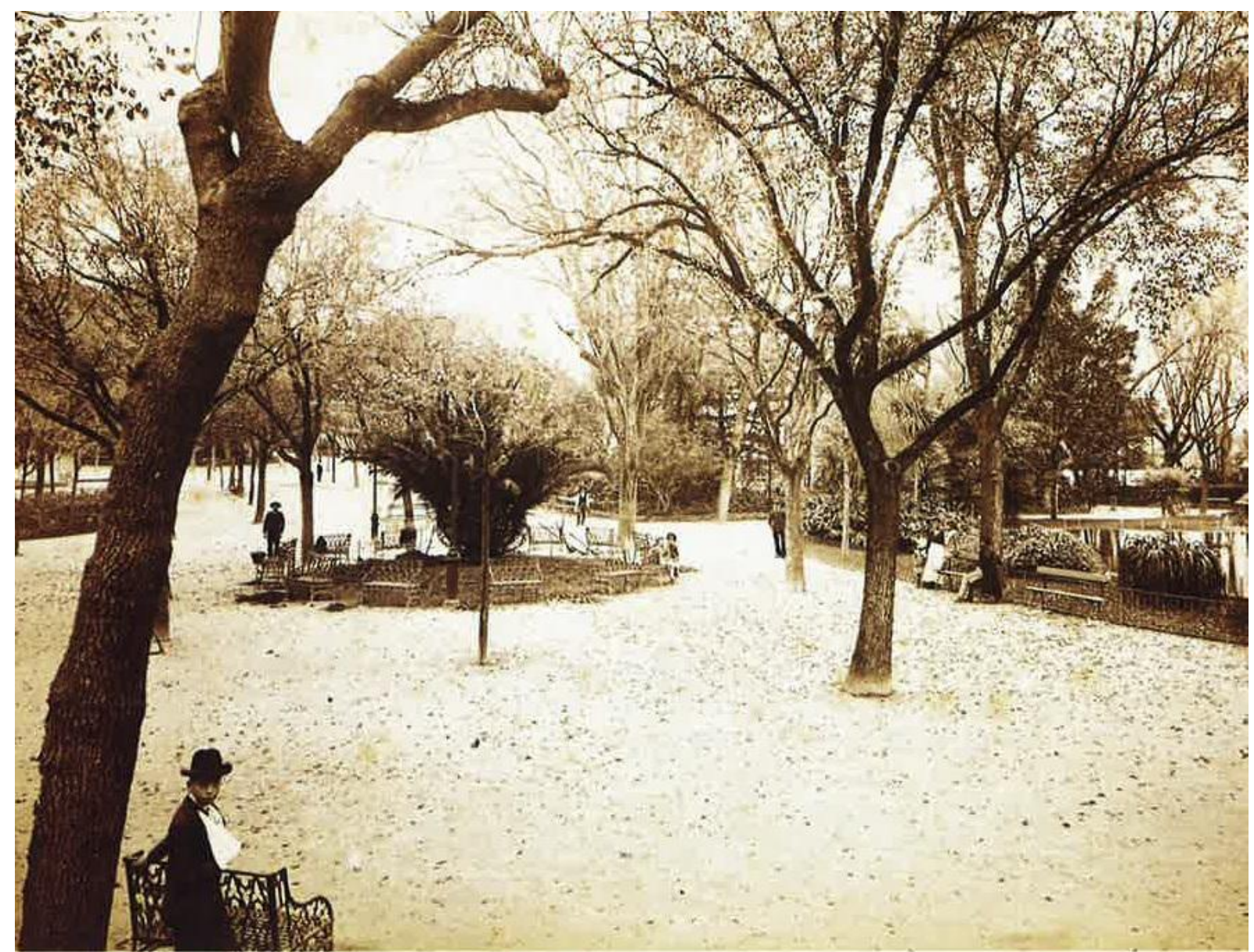

Fig. 3. Bancos de ferro fundido no Jardim da Estrela, Lisboa. Provas Originais, 1858-1910. Lisboa, AFML, 1994, p. 36 (col. Eduardo Portugal)

O Jornal de Horticultura Prática ${ }^{15}$ foi também um enorme divulgador em matéria de mobiliário para jardim, das novidades nacionais e estrangeiras. Publicita vários modelos de bancos em ferro e madeira: o banco Derby ${ }^{16}$, com toldo, da casa J. \& G. Haywood, de Derby, Inglaterra; o banco Bulrusk, também inglês, produzido e comercializado pela Barnard Bishop \& Barnards, de Norwich, com molas de aço!, de grande conforto, em geral pintado de verde ou "bronzeado"17, ou da cor que o encomendador pretenda; um outro modelo de banco com toldo, também da responsabilidade da Barnards ${ }^{18}$. A mesma tipologia, sem toldo, numa curiosa versão prolongada e a acompanhar a curva do jardim, encontramos nos nossos jardins, nomeadamente num palacete na avenida duque de Loulé (Fig. 4). Em Portugal, o verde, não tendo sido a cor exclusiva, poderá ser a cor mais comum até ao presente. Os catálogos dos Armazéns Grandela, fundados em 1891, anunciam "bancos de ferro para jardim com réguas pintadas de verde."19

Um modelo de banco mais simples, com estrutura em ferro, difundiu-se em jardins púbicos mas também domésticos, a partir dos anos 70/80 de Oitocentos. A armação obedece a um naturalismo que sugere troncos de madeira, requinte de execução só possível com o ferro fundido. Quer as costas, quer o assento recebem uma ou duas peças de madeira, de dimensão diferenciada, frequentemente 
arredondadas nas extremidades (Fig. 5). A mesma estrutura em troncos simulados pode apresentar um revestimento de cortiça (Fig. 6), muito requisitada pelo espírito bucólico (mas erudito) da época. Vemos a matéria-prima do sobreiro transformada em cadeiras, bancos e mesas, pontes sobre pequenos lagos e sebes, como se fez no jardim do palácio Palmela, ao Rato, em 1857. Recebeu um gradeamento de cortiça pelo custo de $129 \$ 730$ réis $^{20}$.

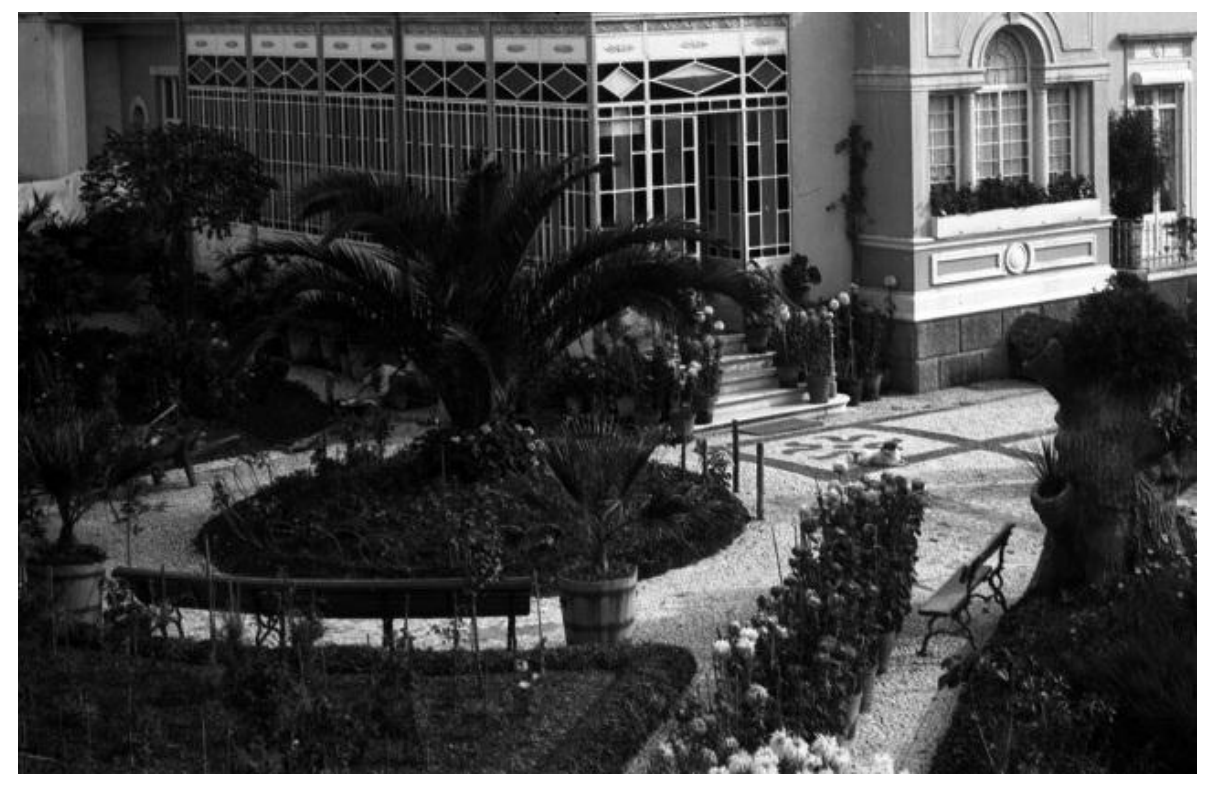

Fig. 4. Banco curvo; vasos em fila; jardim doméstico de palacete na avenida duque de Loulé, Lisboa. AFML, fotografia de Alberto Carlos Lima, LIM000956

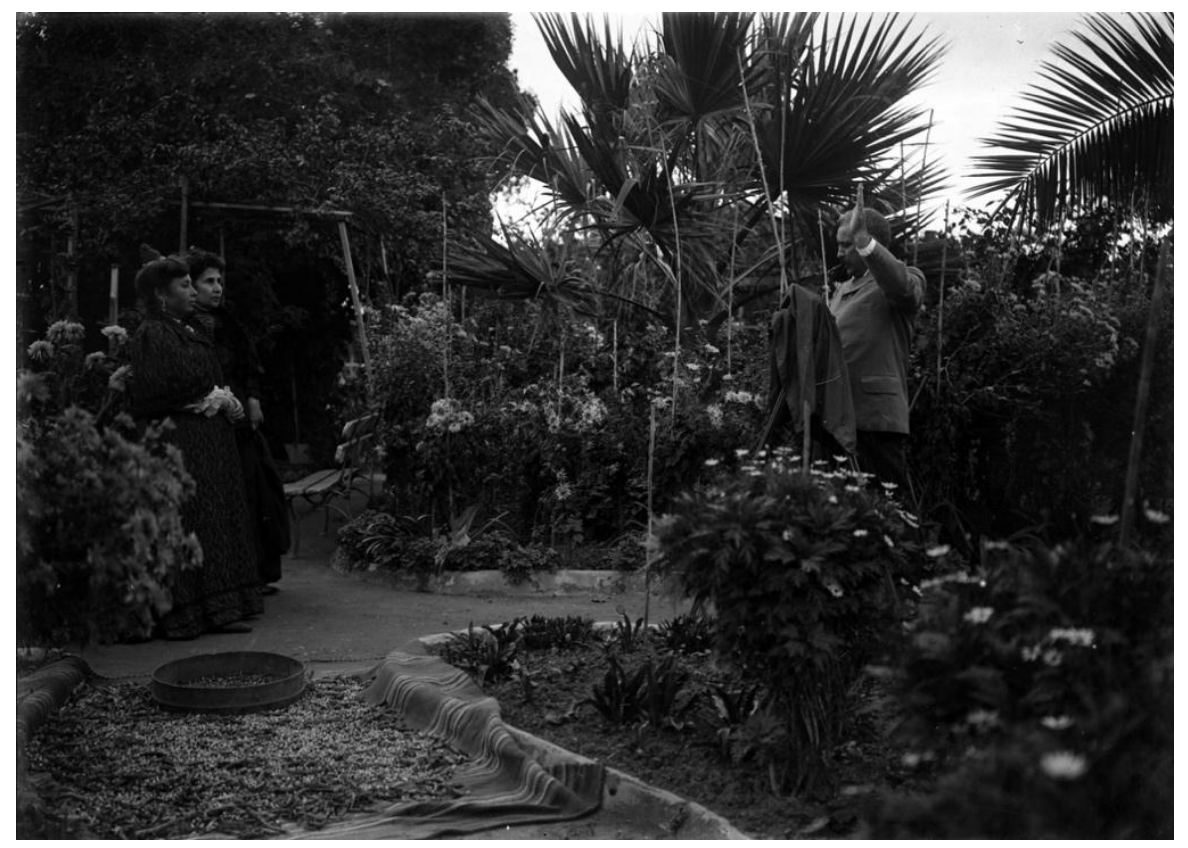

Fig. 5. Banco de madeira e ferro em jardim doméstico não identificado. AFML, fotografia de Alberto Carlos Lima, A14721 


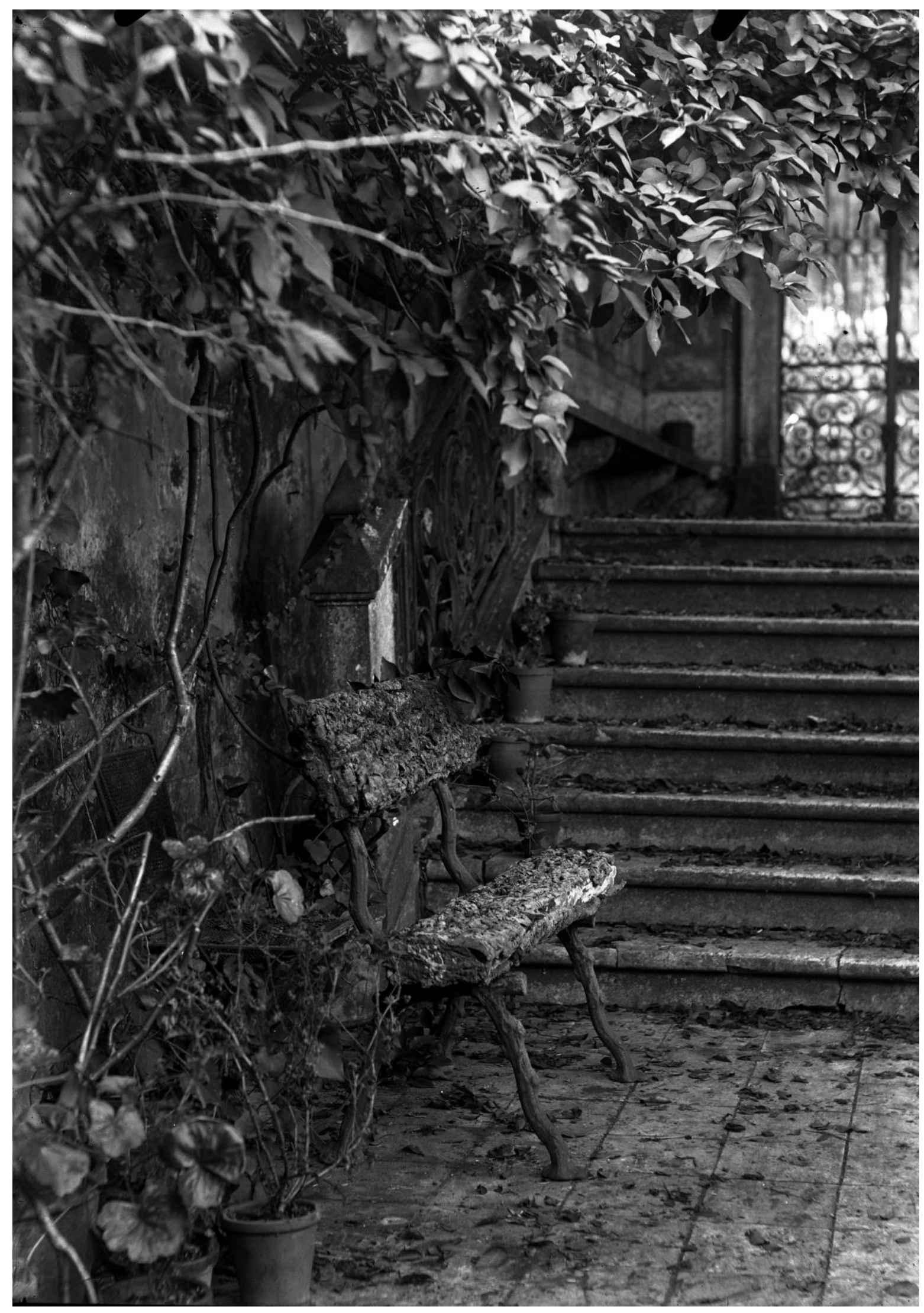

Fig. 6. Banco de cortiça e ferro do palácio da Mitra, Lisboa. AFML, fotografia de José Artur Bárcia, BAR001006 
Igualmente designados bancos, surgem móveis de assento cerâmicos, ou de louça, totalmente distintos dos já referidos. Ainda que preencham o requisito funcional, respondiam essencialmente a um requintado propósito decorativo. Trata-se de bancos individuais que refletem o gosto generalizado nas restantes peças de louça de maior qualidade, de faiança ou porcelana. A forma mais comum, bojuda, como se uma pipa fosse, clara importação orientalista, vemo-la no jardim de Inverno do Palácio da Ajuda, por exemplo, ou na estufa do palácio Burnay (Fig. 7). Também de uso individual, no registo das representações artísticas de serviçais, como as figuras de convite ou os criados-tocheiros, são os "Blackmoors", executados com grande verismo pela manufactura inglesa Minton $^{21}$. Este par de meninos-criados negros, sentados numa almofada, a suportarem outra sobre a cabeça, de cores vivas e contrastantes, integravam os aposentos da condessa d'Edla, segunda mulher do rei Fernando II, no palácio das Necessidades.

As cadeiras são também peças-chave no jardim da casa. Terão sido elas, vindas do interior doméstico, a espoletar a especialização de mobiliário para jardim? É certo que vamos encontrando sempre esta contaminação entre o dentro e fora, principalmente no que respeita a cadeiras. Feitas de vime ou de verga, se não chegam, trazem-se da sala, por exemplo, as chamadas austríacas ou Thonet, leves, desfrutando a família, os amigos, do ar do campo, mesmo que a paisagem doméstica se apresente descuidada (Fig. 8).

Sem surpresa, também o ferro é muito utilizado na matéria-prima destes móveis de assento. Os catálogos de divulgação dos produtos Grandela, inovação do marketing comercial oitocentista, apresentam "cadeiras de ferro, género austríaco, próprias para jardim" 22 , perfuradas, quer no assento, quer nas costas. $\mathrm{O}$ desenho Thonet, na simplicidade e leveza, tornam-no, pois, comum à casa e ao jardim, na primeira de madeira, no segundo, apropriadamente de ferro.

A par do ferro fundido, o trabalho na forja continua também a ser utilizado, como verificamos nas cadeiras de braços colocadas junto a um dos lagos dos jardins do palácio Fronteira (Fig. 9). Para a construção da arqueologia dos jardins desta casa nobre, originariamente seiscentistas, notamos que em Oitocentos, sobre a geometrização da composição do jardim Grande, foi aposta uma forte atmosfera naturalista, pelo tipo, quantidade e volume de plantas a habitar cada canteiro, o que impõe uma releitura do formalismo original, retomado novamente no século XX.

O Jornal de Horticultura Prática divulga, em 1876, um modelo de cadeira de ferro ${ }^{23}$, sugerindo produção nacional, "simples e elegante", com vantagens em relação à cadeira de cortiça, mais cómoda, mais duradoura e mais barata. Cinco anos mais tarde, mostra dois modelos da Barnard Bishop \& Barnards, também em ferro, uma cadeira menos ambiciosa, outra de braços, com as costas e o assento em aço encanastrado, proporcionando grande conforto: "é uma cadeira para sentado nela e fumando um bom charuto, se passar horas e horas a contemplar, em serena tarde de estio, as nuvens subtis que perpassam sobre a nossa cabeça (...)." 24 


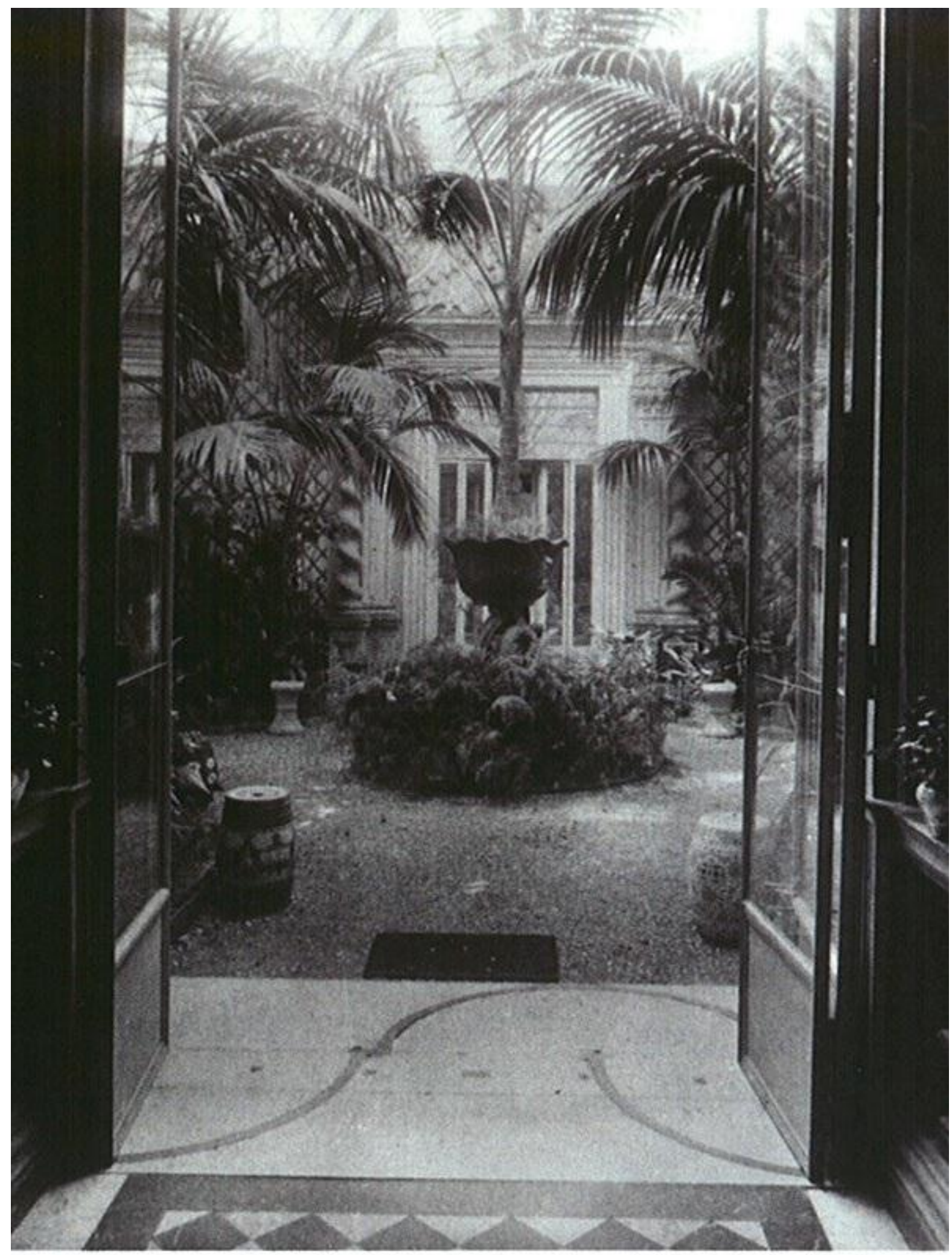

Fig. 7. Bancos de louça oriental na estufa Poente do palácio Burnay, Lisboa. Publ. Burnay: o Palácio da Junqueira [Catálogo]. Instituto de Investigação Científica Tropical/Câmara Municipal de Lisboa, [2008], s.p. 


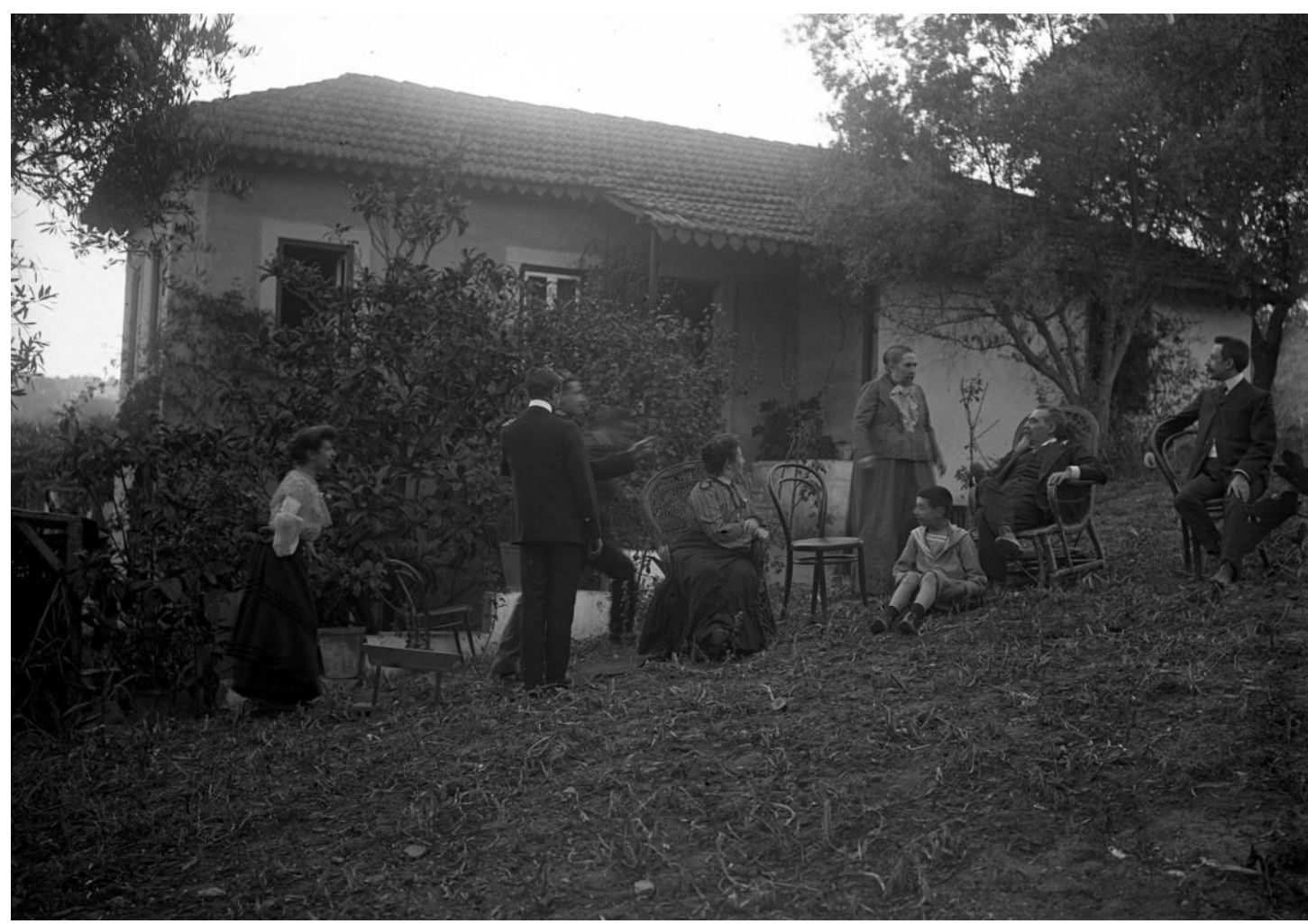

Fig. 8. Cadeiras Thonet; cadeiras de vime; terreiro doméstico não identificado. AFML, ACU001792

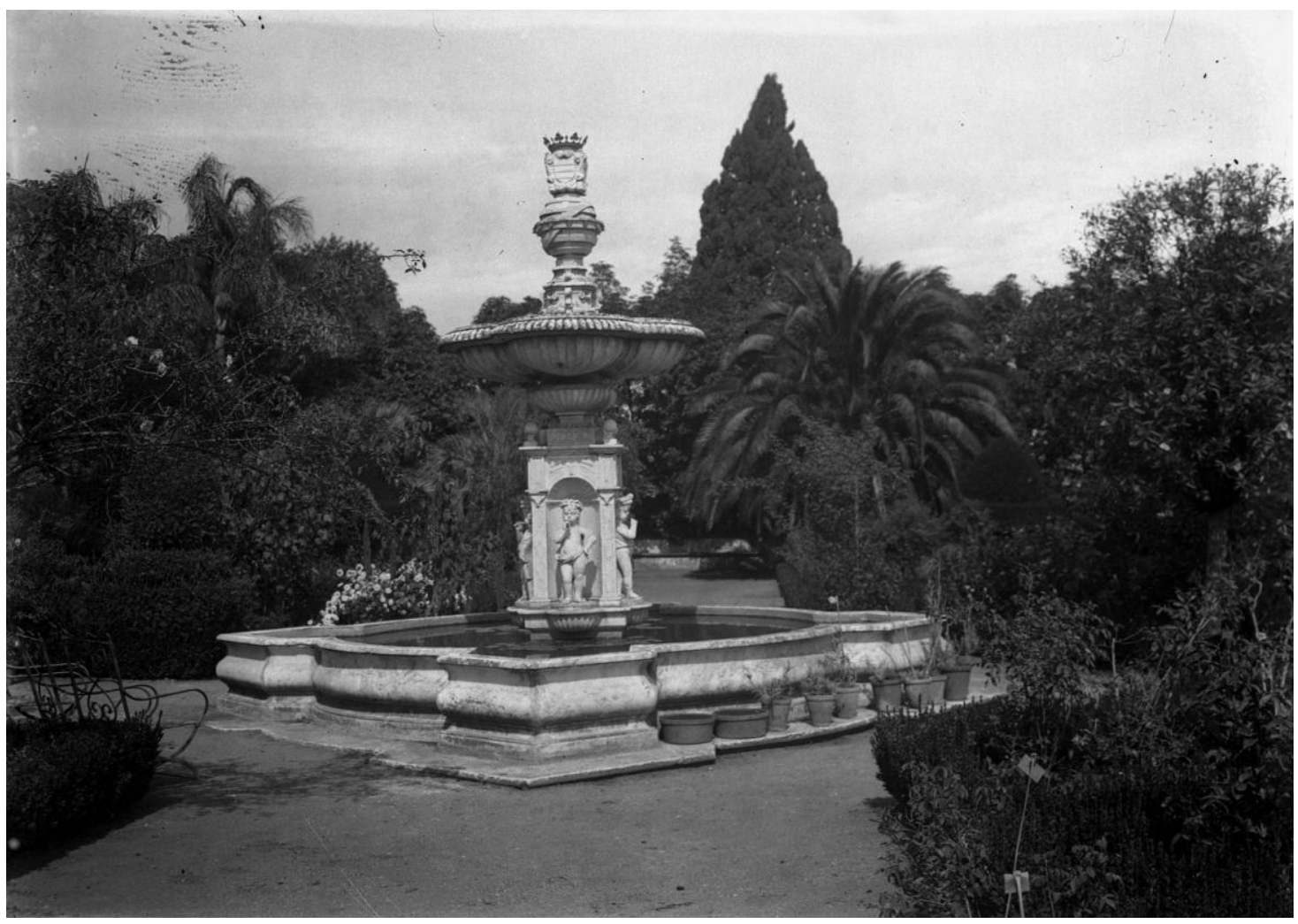

Fig. 9. Cadeiras de braços de ferro forjado no jardim do palácio Fronteira, Lisboa. AFML, fotografia de Joshua Benoliel, JBN002248 
O mote do naturalismo é seguido também para as cadeiras. À semelhança da qualidade plástica dos troncos em ferro fundido, encontramos recorrentemente a recriação da natureza a partir da madeira. Numa execução mais requintada, apropriada a um espaço interior, pode receber douramento, como vemos nos canapés e cadeiras de sugeridos troncos de bambu. Estes móveis integram o ambiente decorativo autêntico ${ }^{25}$ preservado ainda hoje no jardim de Inverno do Palácio da Ajuda, ideado em 1865 pelo arquiteto Joaquim Possidónio da Silva, para os monarcas portugueses, Luís I e Maria Pia ${ }^{26}$.

Encontramos a mesma sugestão de troncos de madeira no conjunto bastante completo de móveis que equipavam o jardim da actriz Lucinda Simões (1850-1928), da sua casa em Benfica (Fig. 10). Vemos várias cadeiras que circundam um banco redondo, também de madeira, colocado, este, em torno de uma sombrinha, provavelmente de folha de alumínio pintado. As cadeiras evidenciam uma montagem de vários troncos de madeira, nos pés e nas costas, concretizando uma clara intenção de rusticidade.

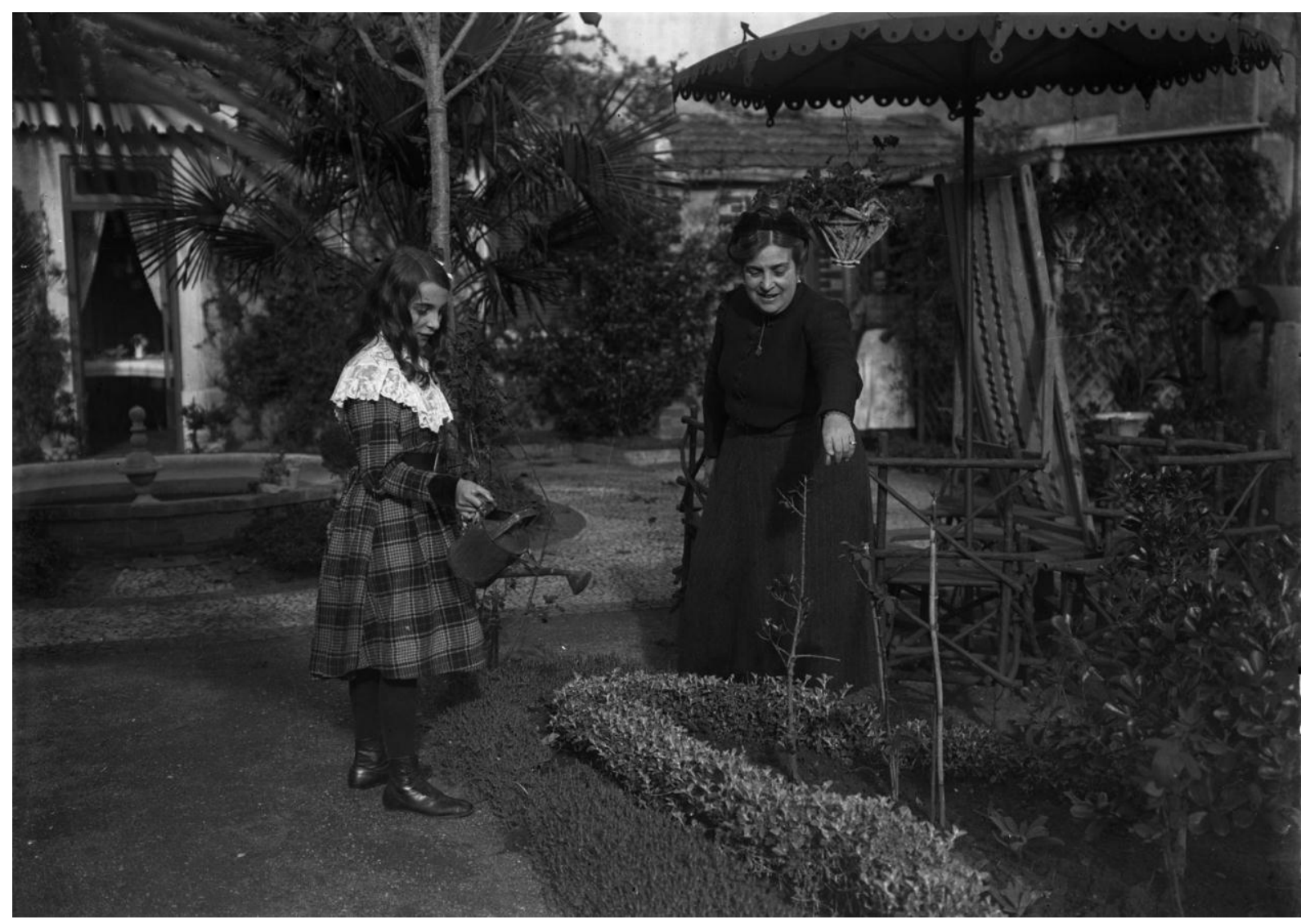

Fig. 10. Cadeiras de madeira, sugerindo troncos, no jardim da actriz Lucinda Simões, Lisboa. AFML, fotografia de Joshua Benoliel, JBN002870. 
No retrato encontra-se também uma cadeira-espreguiçadeira, por abrir, com tecido riscado. Este tratamento simples da madeira ainda hoje continua a ser muito requisitado.

A variedade de peças do jardim de Lucinda Simões, fixadas por Benoliel, merece menção mais detalhada. O beiral da sombrinha é formado por uma franja que, de oito em oito, apresenta um recorte, com orifício, apropriado à suspensão de uma lanterna, eventualmente com vidro colorido. Acesas à noite, reescreveriam uma outra cenografia para o jardim, permitindo a sua fruição.

Do mesmo beiral pendem duas floreiras para vasos, peças que se encontram no exterior, portanto, mas que também são passíveis de integrar o interior doméstico. O Jornal de Horticultura Prática publicita vários modelos de suspensão, numa clara apologia do uso das plantas dentro de casa: desde simples anéis ou argolas em ferro, vazados para encaixe do vaso, divulgados em $1872^{27}$, a modelos em ferro fundido, presos à parede, para um, dois ou até cinco vasos ${ }^{28}$. Estas floreiras de suspensão podem também ser de louça, indicadas para plantas que exijam mais terra e menos humidade, ou de arame galvanizado. "O que haverá mais belo do que uma cesta com plantas entre os cortinados de uma janela?", interroga o redactor do Jornal de Horticultura, Duarte de Oliveira Júnior, adiantando que tinha já tido, no seu gabinete de trabalho, uma destas "suspensões" com fetos, saxífragas e erva-da-fortuna ${ }^{29}$, "produzindo um bom efeito.

Outra matéria-prima, o vime, a verga ou cana, é recorrentemente usada para canapés, cadeiras e mesas. Um variado leque de ambientes decorativos e círculos sociais reclama estes móveis, que tiveram na ilha da Madeira um grande centro de produção ${ }^{30}$, ainda hoje activo. Encontramos inúmeros testemunhos documentais: num qualquer palácio da família real, na Pena (Fig. 11), em Sintra, nas Necessidades ${ }^{31}$, em Lisboa, na bateria da Cidadela, em Cascais ${ }^{32}$, nas quintas aristocráticas, como a dos Azulejos, no Lumiar (Fig. 12), ou em atmosferas burguesas mais anónimas (Figs. 8 e 13).

Como os bancos e as cadeiras, as mesas integram o leque de peças essenciais para mobilar um jardim. A pedra continua a ser utilizada, prolongando uma tradição vinda de séculos anteriores. O ferro também nas mesas tem largo campo de utilização. "Boa e barata" é a mesa de produção inglesa que o Jornal de Horticultura Prática apresenta em 1880. Com três pés de desenho simples e um tampo de folha perfurado, permitindo drenar águas pluviais, "sobre ela poderemos colocar os copos do refresco, a chávena do café, o livro ou os jornais."33

O jardim da actriz Lucinda Simões apresenta, para além dos móveis já referidos, uma pequena mesa redonda em ferro fundido, de grande qualidade de execução, com um pé de nítida inspiração vegetalista (Fig. 14).

De ferro são também os modelos de mesa anunciados no catálogo dos Armazéns Grandela, um mais simples, "para jardim”, ao preço de $2 \$ 400$ reis ${ }^{34}$; outro, mais elaborado, fazendo parte de um "Jogo para jardim", a englobar, para além da mesa, "sofá" e "dois fauteuils", com "pintura fingindo cana" (Fig. 15), custando $21 \$ 000$ reis $^{35}$. 
Mesas de vime encontram-se, por exemplo, dois modelos na quinta dos Azulejos, ao Lumiar: um redondo e outro de três tampos rectangulares, desnivelados, permitindo pousar a diferentes alturas (Figs. 12 e 16).

Ramalho Ortigão (1836-1915), grande jornalista e escritor, em 1889 acusa a fábrica de louça das Caldas da Rainha de não ter posto à venda "caixas oblongas destinadas a conter vasos de flores", para os peitoris das janelas. Se tivesse produzido "leves caixilhos de ferro ou de zinco", com fácil revestimento a azulejo, proliferariam "jardinzinhos suspensos" em cada janela das casas de Lisboa, transformando o "aspecto geral da cidade." 36

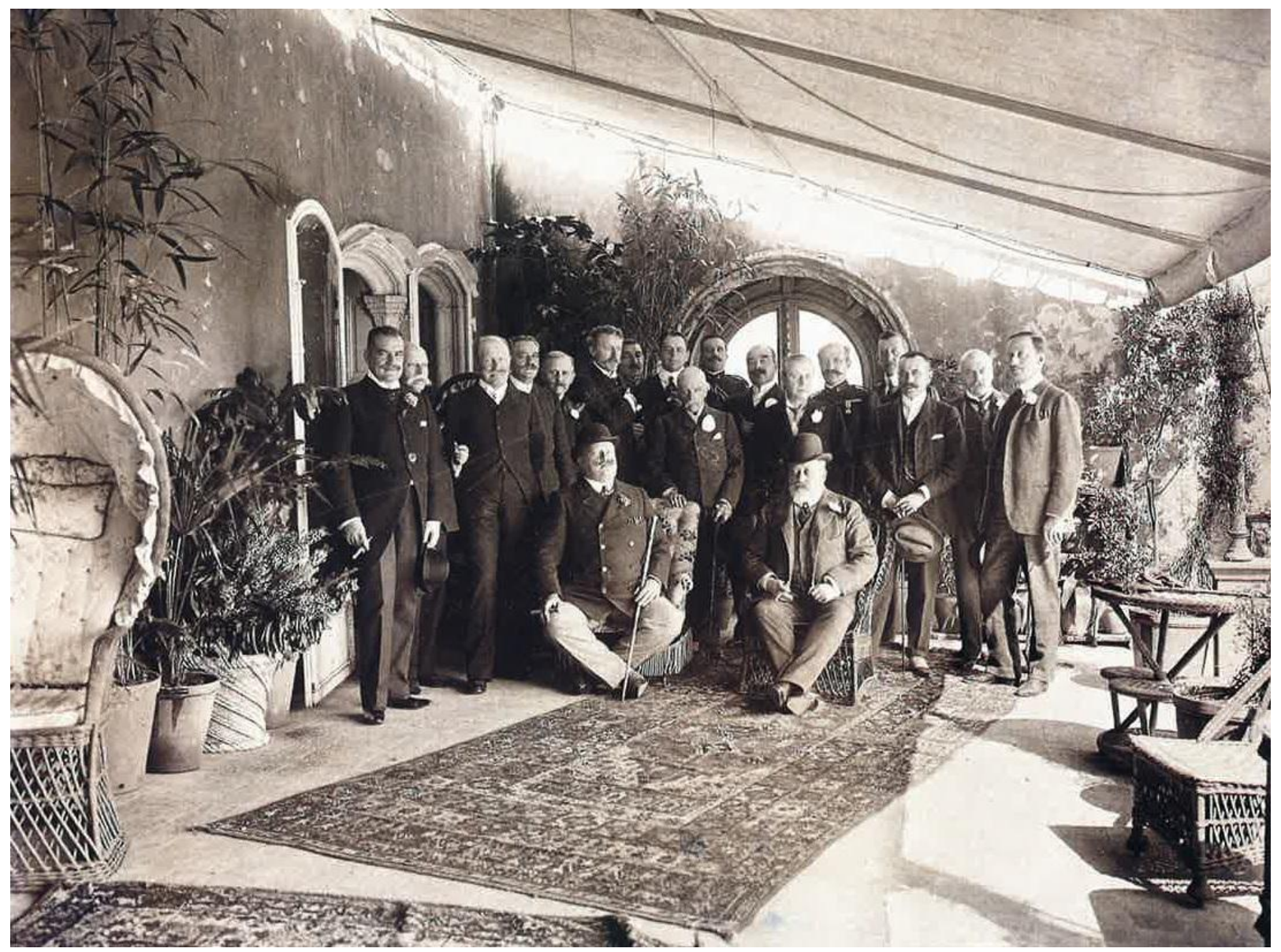

Fig. 11. Cadeiras, mesas e vaso de vime no palácio da Pena, em Sintra. Sentados, os monarcas, D. Carlos de Portugal e Eduardo VII de Inglaterra. Provas Originais, 1858-1910. Lisboa, AFML, 1994, p. 84 


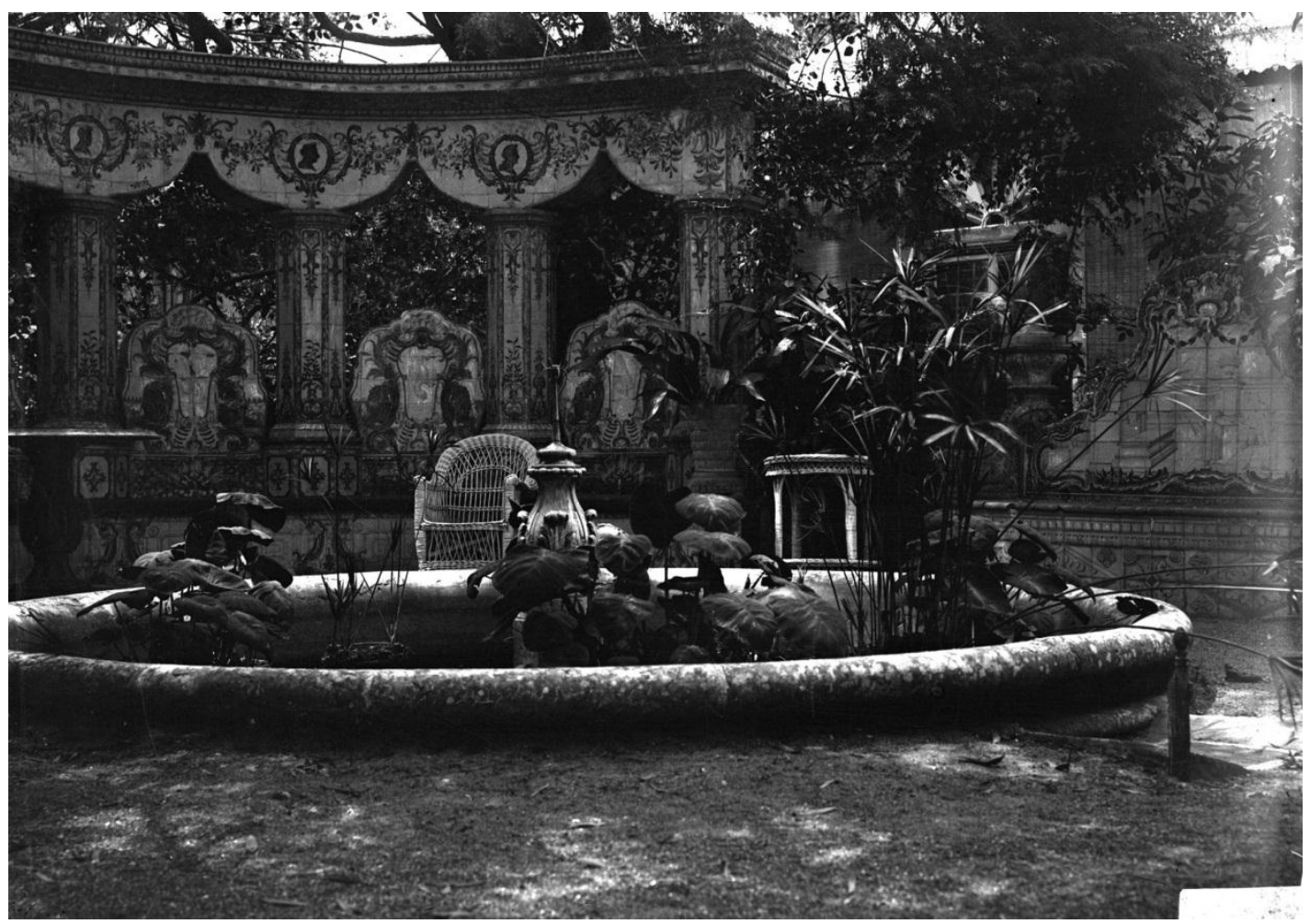

Fig. 12. Cadeira e mesa de vime na quinta dos Azulejos, Lisboa. AFML, fotografia de José Artur Bárcia, AR000249

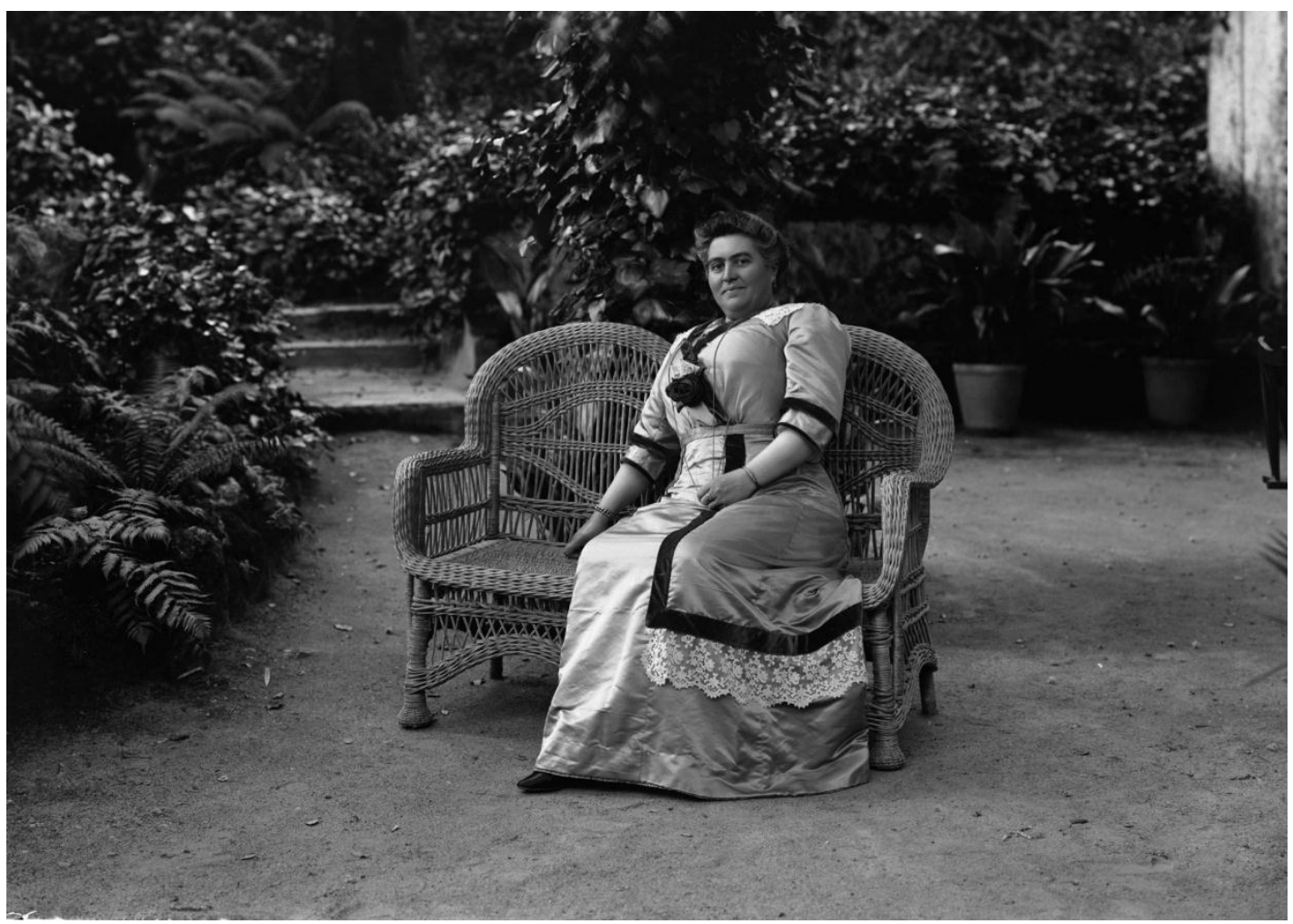

Fig. 13. Canapé de vime em jardim doméstico não identificado. AFML, NEG000104 

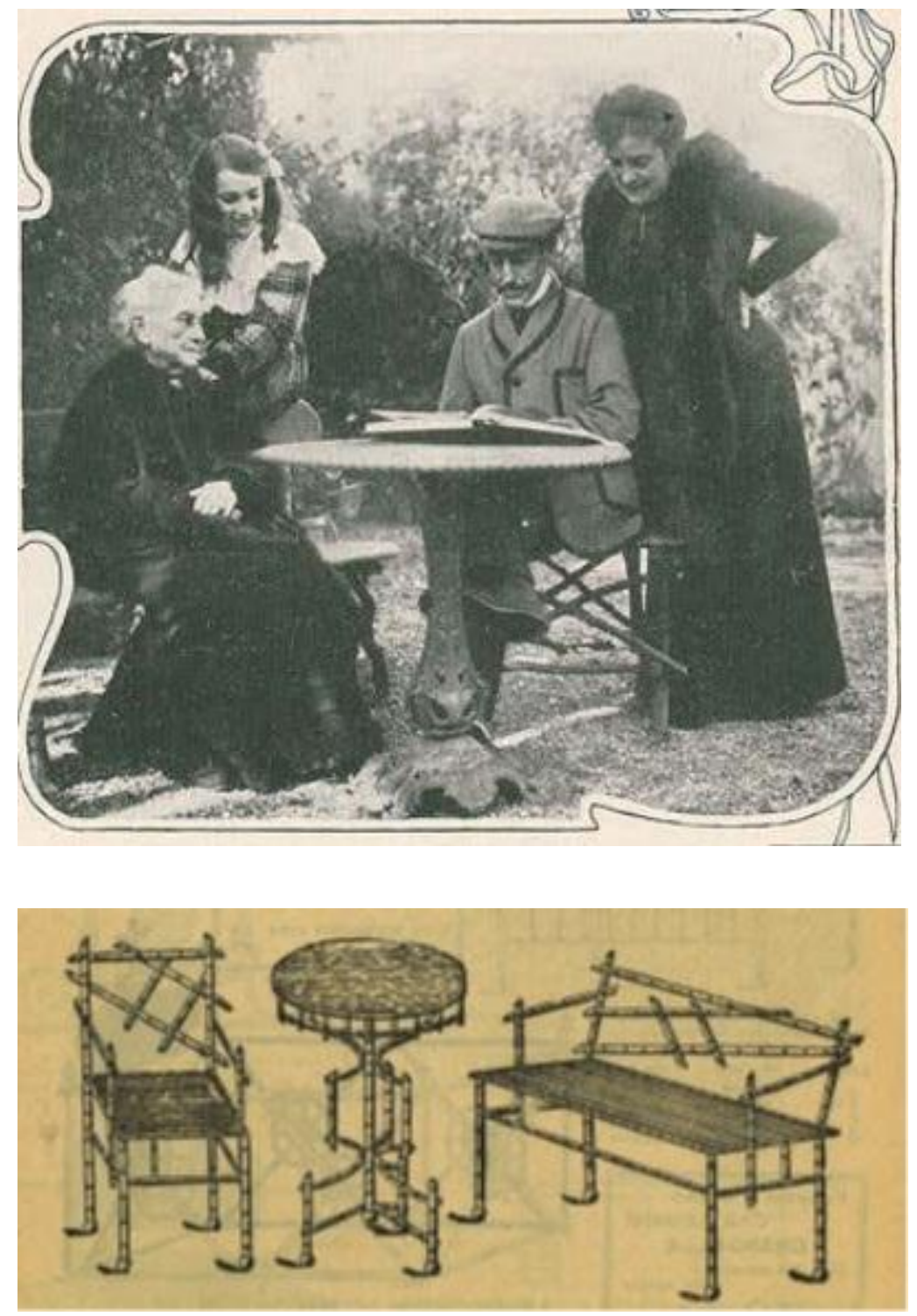

Fig. 14. Mesa de ferro fundido no jardim da actriz Lucinda Simões, Lisboa. [Fotografia de Joshua Benoliel] publ. Ilustração Portuguesa, 1909, Dezembro, 27, p. 808

Fig. 15. Conjunto de ferro para jardim, imitando cana. Publ Armazéns Grandela (...), op. cit., p. 57.

Ramalho lamenta a falta de adesão a este móvel de janela, responsabilizando a manufactura por não ter tido visão para fabricar este produto, contrariamente ao que ocorreu, por exemplo, na Grã-Bretanha. Neste país generalizaram-se, no meio urbano, janelas ornamentadas com caixas no peitoril, preenchidas de flores e plantas.

No entanto, o Jornal de Horticultura Prática publicita, em 1872, vários modelos destas "caixas de plantas para janelas", o que sugere a existência de adeptos, abrindo campo a uma expectativa de uso, em contraponto à impressão de Ramalho Ortigão. O articulista convida os mais habilidosos a construírem a sua peça, por dentro de madeira e por fora forrada ao gosto pessoal, identificando a cortiça, a madeira de sobreiro ou ramos de videira como materiais possíveis. Outra solução é a encomenda, como já fez na cidade do Porto, adianta, Duarte Oliveira Júnior, o redactor do Jornal. Dá conta de quatro modelos da casa londrina Dick Radclyffe \& $\mathrm{C}^{\circ}$., aconselhando o acerto entre a arquitectura da casa e o modelo de caixa (ou caixas) a escolher, pois "seria de mau gosto colocar na frontaria de um edifício de custosa arquitectura uma caixa que (...) diria 
perfeitamente num chalet ou numa poética cottage." 37 Para fachadas mais eruditas as "caixas de luxo, ricas, elegantes, de madeira lavrada ou louça", portanto com a aplicação de azulejos ${ }^{38}$; para os ambientes domésticos mais simples, "feitas de madeira tosca ou cortiça." 39 E quais as plantas mais indicadas? Trepadeiras, arbustos, plantas bolbosas e pequenas flores como os amoresperfeitos, as violetas, as prímulas, as gazânias e as cravinas.

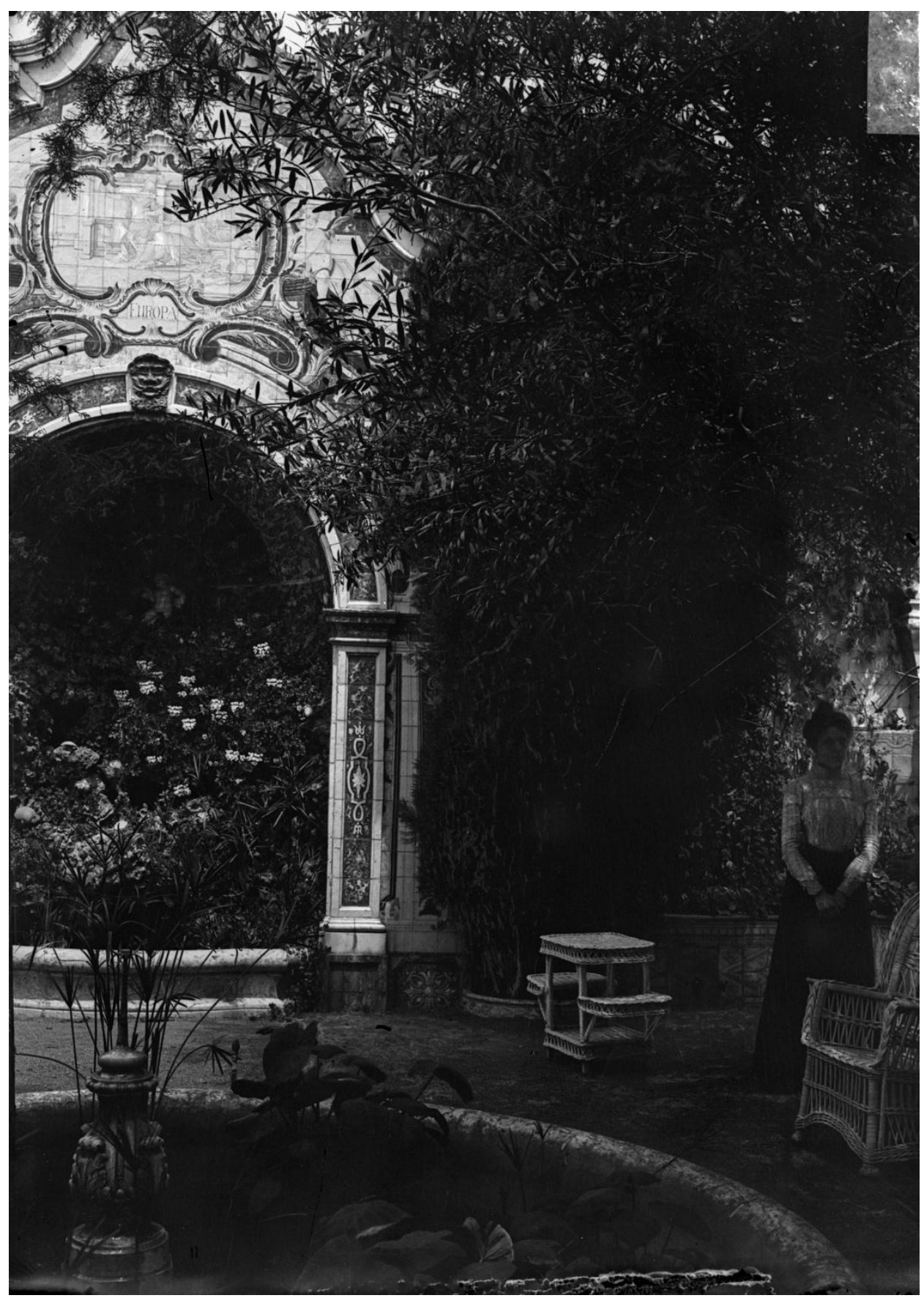

Fig. 16. Cadeira e mesa de vime na quinta dos Azulejos, Lisboa. AFML, Fotografia de José Artur Bárcia, BAR000248 
Os vasos pululam na segunda metade de Oitocentos, quer no interior doméstico, quer nos jardins. Nestes, ao lado de canteiros, bordejando-os (Fig. 17), formando filas (Fig. 4), ou pontuando (Fig. 18), colocam-se na versão mais clássica, em barro cozido ou pintado. Distribuídos pelo perímetro do jardim, encontramo-los em pedra, ferro fundido, em madeira ou em faiança. Assinalando entradas, escadarias ou outros ritmos dados pelo desenho dos jardins, identificam-se frequentemente de ferro ou de faiança. No jardim do palácio Palmela, ao Lumiar, vemos dois modelos (Fig. 19): o mais simples a acompanhar exaustivamente o ritmo da escadaria do jardim, o vaso com pé, à grega, a pontuar os remates dos muretes.

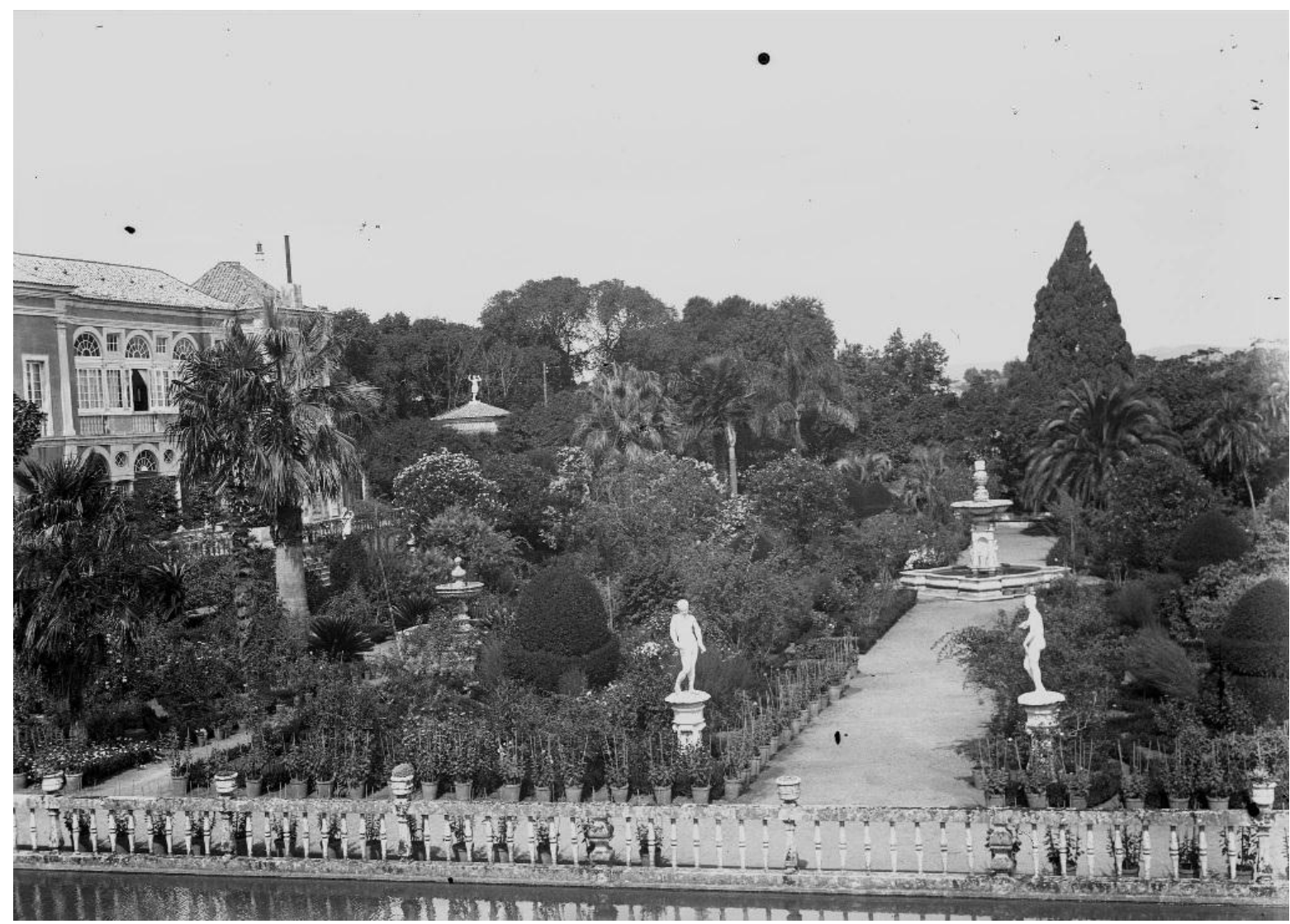

Fig. 17. Vasos de barro bordejando canteiros nos jardins do palácio Fronteira, Lisboa. AFML, BAR000249 


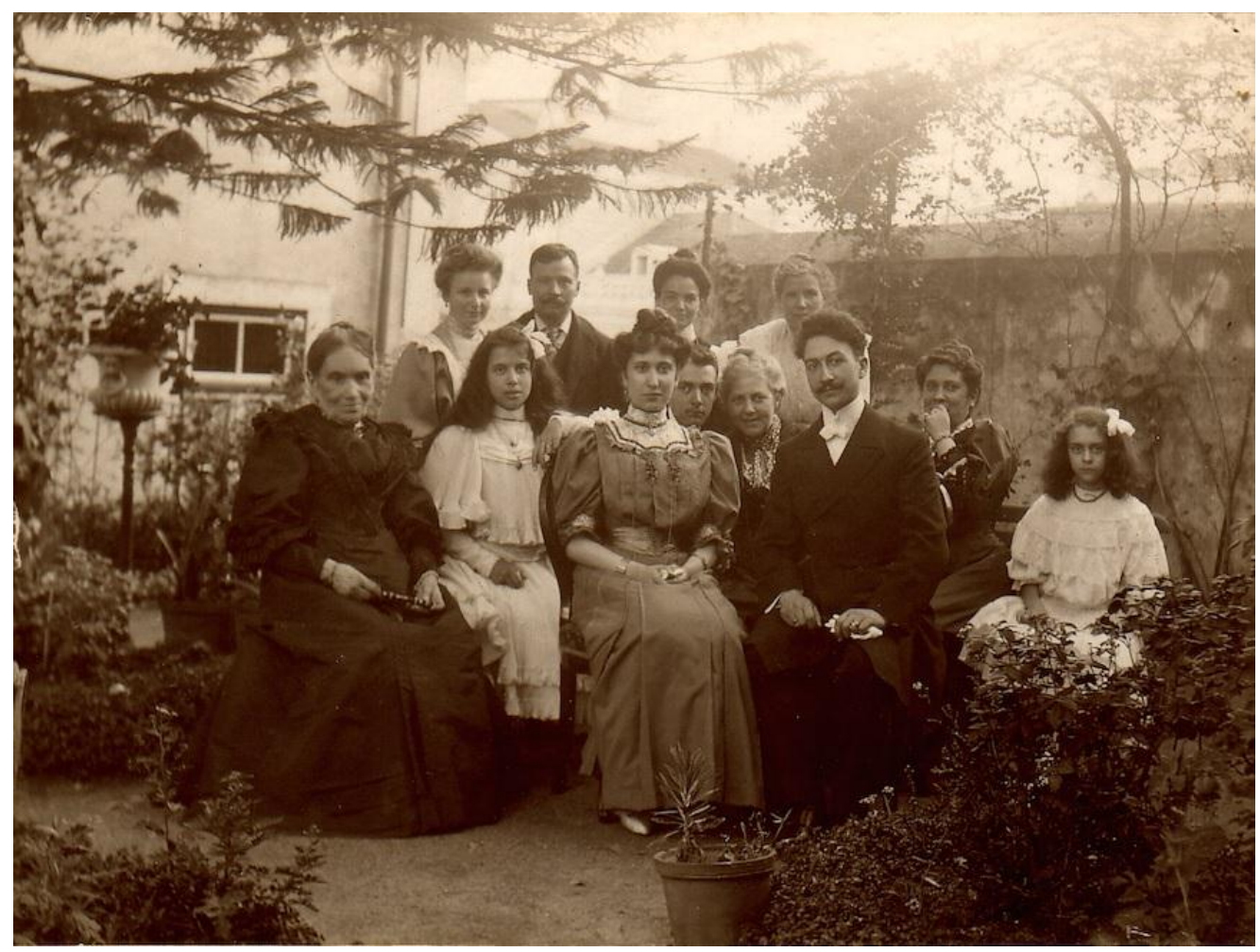

Fig. 18. Vaso em faiança sobre coluna de ferro fundido no jardim doméstico dos descendentes do marceneiro Pedro Bartolomeu Dejante, Lisboa. Publ. em Celina Bastos, op. cit., p. 168. Col. Inês Thomas Almeida

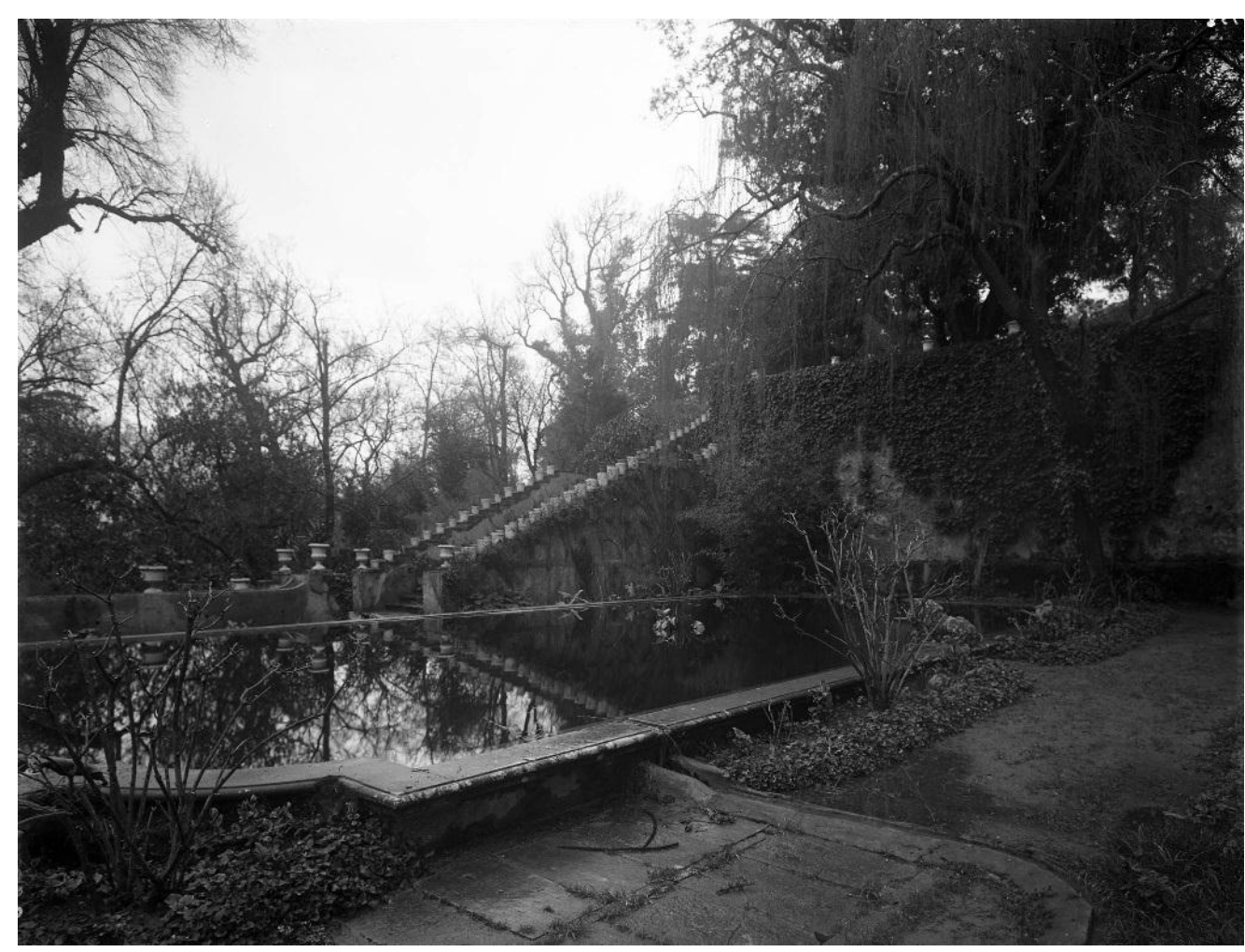

Fig. 19. Vasos de faiança nos jardins da quinta do Lumiar, da família Palmela, Lisboa. AFML, ACU002529 
No interior doméstico os vasos espalham-se por várias divisões da casa, das salas aos quartos, nas varandas e alpendres. No palácio do Manteigueiro, em Lisboa, onde veio a habitar o primeiro Presidente da República, Manuel de Arriaga, a varanda envidraçada preenchia-se com flores e plantas ornamentais (Fig. 20), em vasos de barro colocados sobre o chão ou sobre jardineiras simples, circulares, em ferro.

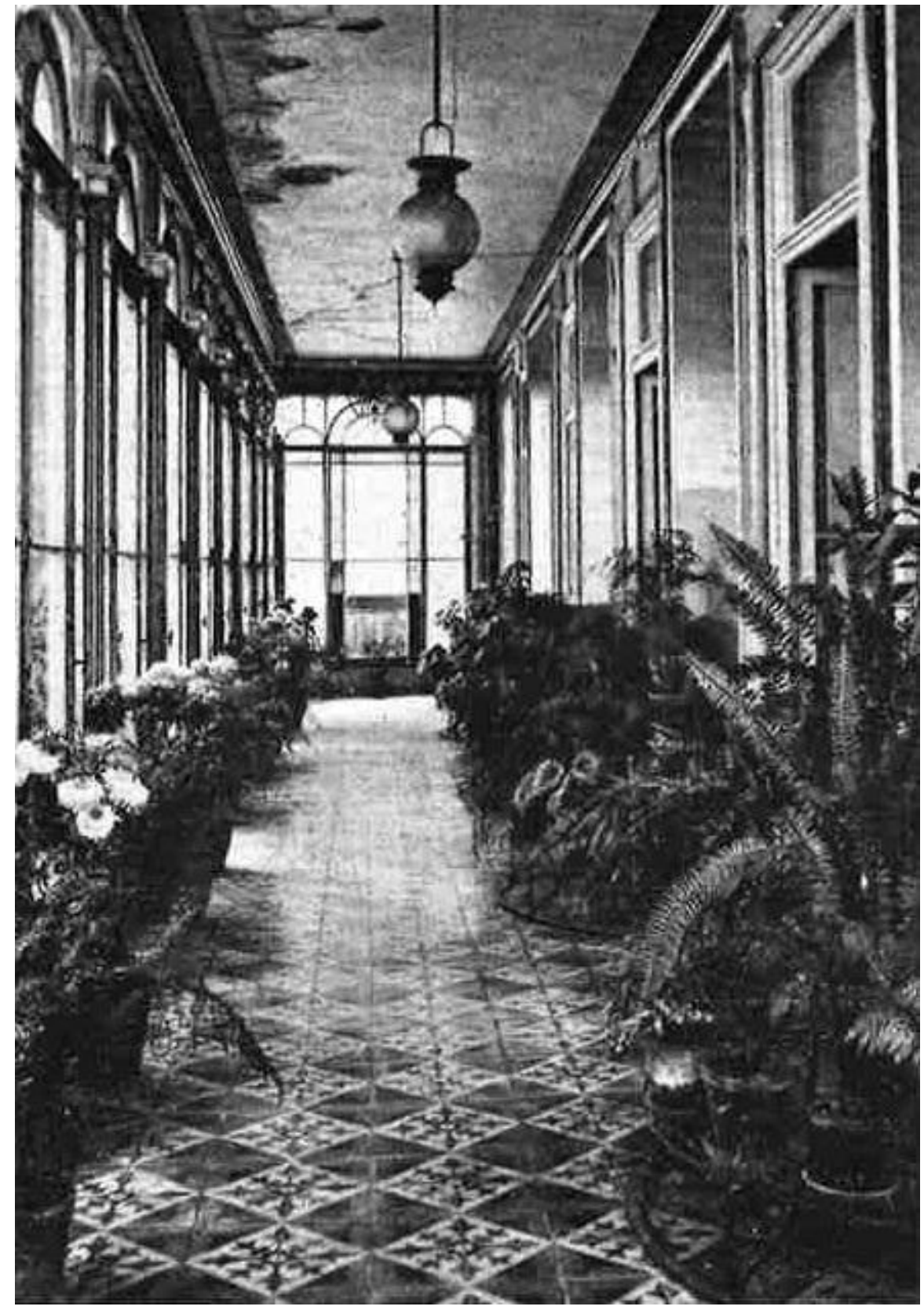

Fig. 20. Vasos e jardineiras no palácio do Manteigueiro, Lisboa. Publ. Ilustração portuguesa, 1912, Janeiro, 1, p. 36 
Em momentos festivos, os vasos aumentam exponencialmente. Numa festa dada pelos condes de Rio Maior, no seu palácio da Anunciada, em Lisboa, em "todas as salas havia imensas flores, assim como na escada e por baixo dela." 40 No palácio Palmela, ao Rato, para um casamento, a escadaria estava repleta de vasos com flores ${ }^{41}$. A família compra-os por diversas vezes: em 1855, em Abril, manda pintar vasos, em Julho adquire 50 e em Setembro mais 104, tudo para os jardins do Lumiar. Para os mesmos jardins, no ano seguinte, adquire vasos no pesado valor de $236 \$ 700$ reis. Em 1857 gasta $87 \$ 840$ reis com a compra e transporte de "12 doze vasos de ferro fundido"; dois anos mais tarde, outra dúzia, agora de porcelana, bastante mais em conta, $11 \$ 530$ reis, uns e outros para o jardim do Rato. Até para o seu jazigo de família, no cemitério dos Prazeres, em Lisboa, são encomendados ${ }^{42}$.

De outros modelos de vasos, eventualmente usados num circuito mais restrito, há vestígios. Eça de Queirós (1845-1900), escritor maior da cultura portuguesa, perpassou, nas suas tramas ficcionadas, sob um olhar vivo e profundo, o Portugal de Oitocentos. Em Os Maias ${ }^{43}$ encontramos vasos do Japão com rosas de Inverno, numa quinta em Benfica ${ }^{44}$, nos arredores de Lisboa; vasos de louça branca, (faiança ou porcelana), com craveiros, no Ramalhete ${ }^{45}$, o palácio da família protagonista; vasos de Ruão, da manufactura francesa, no consultório, ao Rossio, de Carlos da Maia ${ }^{46}$, um cosmopolita do escol lisboeta. No mesmo consultório encontrava-se uma jardineira ${ }^{47}$, aqui sem plantas nem flores, móvel cujo nome não esconde a sua origem semântica, à semelhança da floreira.

Jardineiras e floreiras difundem-se - e confundem-se, por vezes - no seio de um amplo arco socio-económico, tornando-se móveis constantes no interior doméstico oitocentista, mas também no exterior.

A designação "jardineira" é dominante. O termo aplica-se a formas muito distintas, tendo por ponto em comum as flores ou as plantas que apresenta. Alguns modelos diferem muito pouco ou mesmo nada de uma normal mesa de encosto ou de uma consola.

Logo em 1849, na quarta exposição organizada pela Sociedade Promotora da Indústria Nacional, no edifício do Arsenal, em Lisboa, Pedro Bartolomeu Dejante (final do séc. XVIII-1859), industrial e afamado marceneiro francês estabelecido em Portugal desde 1821, apresenta uma jardineira no leque de móveis que leva ao certame. Muitas outras produzirá ao longo dos anos seguintes ${ }^{48}$.

A família Palmela compra jardineiras em 1856 para os jardins da quinta do Lumiar $^{49}$. O Jornal de Horticultura Prática divulga, por diversas ocasiões, modelos de jardineiras. Em 1873 mostra duas propostas do catálogo da já referida casa inglesa Dick Radclyffe \& $\mathrm{C}^{050}$. Uma mais elaborada, a colocar na sala, "ao meio das janelas, entre cortinados", outra mais simples, ambas podem ser montadas pelo próprio cliente. Alguns anos mais tarde, o mesmo periódico publica uma jardineira de fabrico alemão. A sua forma sugere um cesto de meio cano, com quatro pés baixos, feita de pasta de cartão, tornando-a acessível a todas as bolsas: "não é só o rico que pode ter nas suas salas destes belos ornamentos. $\mathrm{O}$ pobre, o menos abastado, também pode agora ter na sua alcova uma pequena jardineira, porque, para a obter, tem apenas a desembolsar alguns vinténs." $51 \mathrm{Um}$ 
outro modelo surge em 1882, uma pequena coluna com pés torneados e um copo no topo, para receber a planta. "Pequenina jardineira", como é designada, a altura do chão permite-lhe receber uma planta que arme e caia, como a saxifraga tormentosa ${ }^{52}$. N'O Primo Basílio, uma outra obra de referência de Eça de Queirós, Lisboa é o palco central da trama amorosa. Na detalhada descrição dos interiores de uma burguesia educada, mas sem fortuna, Eça menciona várias jardineiras em salas mas também em quartos ${ }^{53}$.

A par de jardineiras produzidas em série, surgem móveis de encomenda, peças únicas, de grande requinte artístico, normalmente integrando um programa decorativo completo. Destacamos o borne de inspiração neogótica executado pelo requisitado entalhador Leandro Braga (1839-1897) para o chalet Biester, em Sintra ${ }^{54}$, por volta de 1895. Este móvel de assento normalmente circular, recebia ao centro uma jardineira ou grande vaso, a preencher com plantas de porte pequeno ou médio, normalmente centrados por uma palmeira.

De outro artista da madeira, Zeferino José Pinto (act. 1866-1897), é exposta uma jardineira ou mesa-jardineira no Centro Comercial Portuense, em 189755, de espampanante composição ornamental que, não fosse a coeva designação oficial, e poderia ser confundida com uma mesa de centro. Aqui seria, portanto, para receber vasos com flores e plantas.

Numa configuração totalmente distinta, como se de um grande vaso de oito pés se tratasse, encontramos duas jardineiras (Fig. 21) no Pátio dos Bichos do Palácio de Belém. Com trabalho elegante em ferro fundido, sugerindo a junção de oito peças em treliça, poderão ter sido adquiridas pelo final dos anos 80 de Oitocentos, integradas num importante programa de melhoramentos para receber o príncipe herdeiro, D. Carlos, e a mulher, D. Amélia, que ali viveram até à morte do rei D. Luís, em 1889, ou na transição do século, quando o palácio se tornou residência de convidados régios.

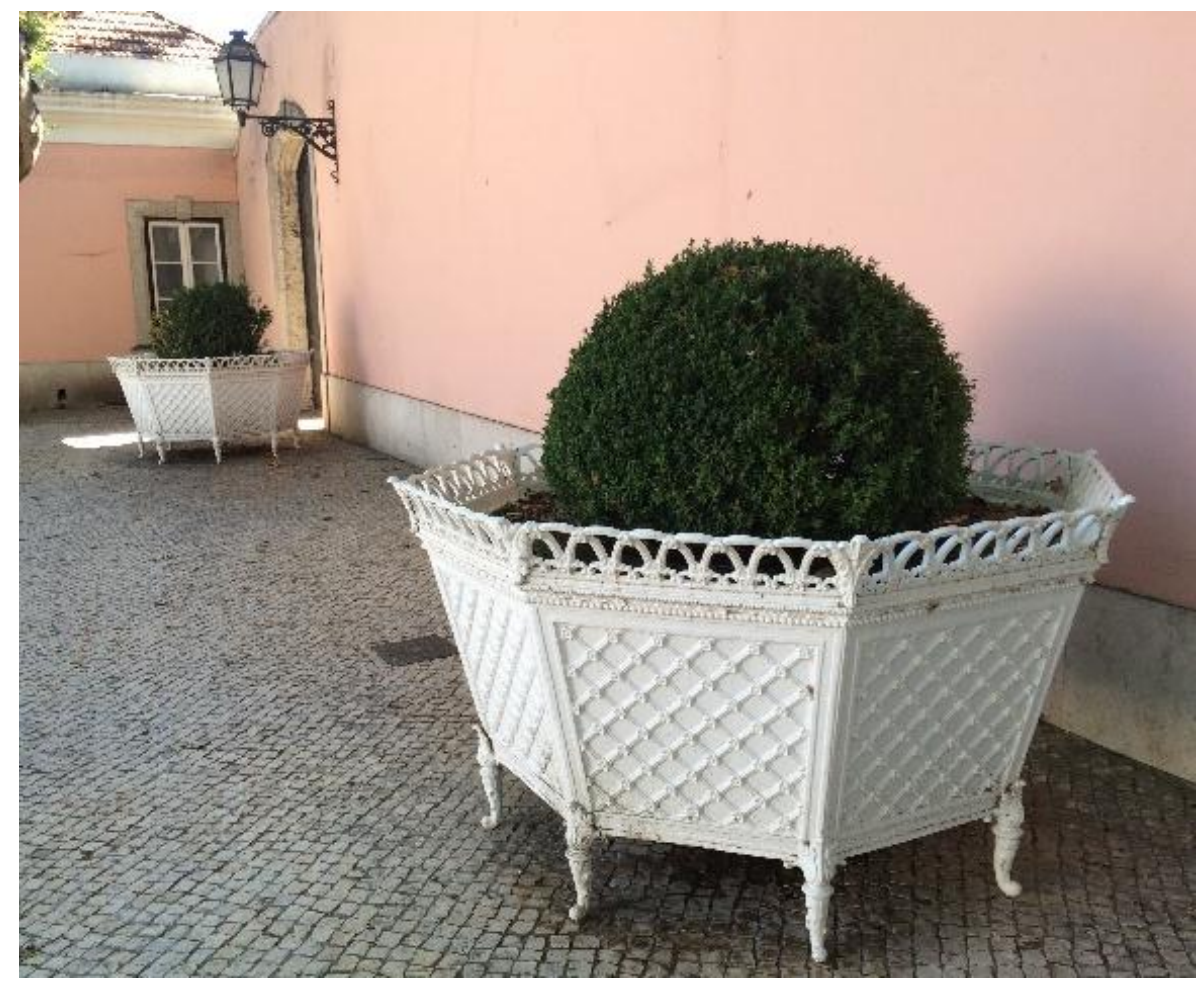

Fig. 21. Jardineiras no Pátio dos Bichos do Palácio de Belém 
Outros móveis poderíamos abordar, convocando fontes que os referenciam, contextualizando o seu fabrico, interpretando as suas características plásticas e funcionais. A completude não foi um propósito, como afirmámos no início deste texto. Se as condições de edição apontariam para tal resultado, mais ainda a nossa consciência de que se trata de uma investigação em curso só poderia consumar um conhecimento em construção.

Privilegiámos o conjunto de móveis que, neste estado da questão, melhor nos parecem caracterizar a atmosfera dos "jardins de fora e de dentro" da casa oitocentista.

Será sustentável afirmar que a produção e o consumo de mobiliário específico para o jardim doméstico andou a par da difusão do gosto pelos jardins, mas também das árvores, plantas, flores per se, numa tendência que atravessa todo o século XIX. Vasos, jardineiras e floreiras invadem espaços domésticos tradicionais, de representação social ou de intimidade familiar, sob pressupostos de coerência formal e estética. Um interior sóbrio, mais simples, pedirá uma jardineira apropriada, um ambiente rústico pedirá um vaso rústico que o jornal, a loja, o catálogo sugerem e comercializam.

Este gosto dá também lugar à criação de espaços de transição ou de fusão. Estufas contíguas à casa, varandas envidraçadas, assumidos jardins de Inverno, configuram frequentemente atmosferas híbridas onde se fundem valores de evocação da natureza e de fruição doméstica. E as cadeiras, os bancos e as mesas que permitem estar, pousar e fruir, sob as exigências de uma nova noção de conforto, medeiam esse diálogo entre o homem e a natureza.

Adensa-se esta mediação quando os próprios móveis se vestem com troncos, com folhas e flores, ficções naturalistas propiciadas pelo trabalho tradicional da madeira ou pela inovação tecnológica do ferro fundido. Mas também o vime, o bambu, a cortiça, matérias-primas recorrentes no mobiliário para jardins, reforçam a evocação do reino vegetal no quotidiano doméstico, como se uma mundovisão ecológica, assumida no século XX, já aqui desse os primeiros passos.

Paralelamente à especialização, frequentemente sofisticada na arte e no engenho, dos móveis pensados e executados para os jardins, documentamos a coabitação de um uso indistinto num amplo círculo social; cadeiras italianas e austríacas, seja no jardim da casa medio-burguesa, seja no jardim do palácio, facilmente se trazem para o exterior, como mesas, cadeiras, de vime ou de bambu, não raramente se encontram no interior.

\section{NOTES}

\footnotetext{
${ }^{1}$ Iniciado em Novembro de 2013, na Faculdade Ciências Sociais e Humanas da Universidade Nova de Lisboa.

${ }^{2}$ Sobre as competências da Camara Municipal de Lisboa em matéria de urbanismo e arquitectura, ver: Joana Cunha Leal, Arquitetura Privada, Política e Factos Urbanos em Lisboa: da Cidade Pombalina à Cidade Liberal. Lisboa, [s.n.], 2005. Tese de doutoramento em História da Arte Contemporânea, apresentada à Faculdade de Ciências Sociais e Humanas/Universidade Nova de Lisboa, pp. 441 e segs.

${ }^{3}$ Estes pareceres pertencem ao acervo do Arquivo Municipal de Lisboa. Estudámo-los exaustivamente em TOJAL, Alexandre A., Malaquias Ferreira Leal, Arquiteto da Cidade na Primeira Metade de Oitocentos: o
} 
Exercício do Poder Regulador sobre a Arquitetura Privada em Lisboa, Lisboa, [s.n.], 2002. Dissertação de mestrado em História da Arte, apresentada à Universidade Lusíada.

${ }^{4}$ OLIVEIRA JÚNIOR, Duarte, "Fogão de Sala Ajardinado" in Jornal de Horticultura Prática, 1883, p. 53.

${ }^{5}$ Referimo-nos ao levantamento da cidade de Lisboa realizado entre 1856 e 1858, sob a direcção de Filipe Folque, na escala de 1:1000, de que resultaram 65 plantas. O Instituto Geográfico Português detém a colecção original. O Arquivo Municipal de Lisboa detém uma cópia realizada pouco anos depois do original ter sido produzido.

${ }^{6}$ Depositado nos Arquivos Nacionais/Torre do Tombo.

${ }^{7}$ Publicou-se no Porto entre 1870 e 1892. Foi fundado por José Marques Loureiro e por José Duarte de Oliveira Júnior, redactor de 1870 a 1887.

${ }^{8}$ SOUTO, Maria Helena, Portugal nas Exposições Universais, 1851-1900, Lisboa, Edições Colibri/Instituto de História da Arte/FCSH/UNL, 2011, p.11.

${ }^{9}$ Revista Universal Lisbonense, 1844, no 9, 19 de Setembro, p. 97.

${ }^{10}$ Idem, ibidem.

11 Ver BARRADAs, Sílvia, A Produção de Mobiliário Urbano de Fundição em Portugal: 1850 a 1920. Barcelona, Universitat de Barcelona, 2015, pp. 84 e segs. Acessível em http://diposit.ub.edu/dspace/handle/2445/67617. [Consulta de 2.ago.2016].

12 Questão tratada por BRAGA, Pedro Bebiano, "A Explosão Ornamental nos Ambientes Decorativos do Período Romântico: o Mobiliário e o Interior Doméstico" in Matrizes de Investigação em Artes Decorativas V, dir. Gonçalo Vasconcelos e Sousa, Porto, Universidade Católica Editora/CITAR, 2015, p. 196: "Mas a grande novidade no fabrico de mobiliário foi a vulgarização do emprego do ferro."

${ }^{13}$ Arquivos Nacionais/Torre do Tombo, Arquivo Palmela, Livro de Receita e Despesa, no 1, fl. 54; mf. 5504.

${ }^{14}$ Genealogia identificada por LE CUNFF, Françoise, Parques e Jardins de Lisboa, 1764-1932: do passeio público ao parque Eduardo VII. Lisboa, [s.n.], 2000. Dissertação de mestrado em História da Arte, apresentada à FCSH/UNL, p. 201.

15 Publicado mensalmente, no Porto, entre 1870 e 1892, teve como proprietário José Marques Loureiro (18301898); "O Jornal foi o instrumento difusor, por excelência, das novas ideias sobre os jardins, as novidades florísticas e os seus cuidados inerentes, os instrumentos de jardinagem, o mobiliário, a silvicultura, a botânica, a filoxera e tantos outros assuntos”, citado por RODRIGUES, Patrick Amaral, A Vegetação Ornamental em Uso na Segunda Metade do Século XIX e a Recuperação de Paisagens de Valor Histórico. Porto, [s.n.], 2015, p. 13. Dissertação de Mestrado em Arquitectura Paisagista, apresentada à Faculdade de Ciências da Universidade do Porto, a partir de Teresa Andresen e Teresa Protela Marques, Jardins Históricos do Porto. Porto, Edições Inapa, 2001, p. 59.

${ }^{16}$ Ibidem, 1872, p. 97.

${ }^{17}$ Ibidem, 1880, p. 97.

${ }^{18}$ Ibidem, 1885, p. 251.

${ }^{19}$ Armazéns Grandela: catálogo especial de mobiliário e tapetes [ca. 1910], p. 47.

${ }^{20}$ Arquivos Nacionais/Torre do Tombo, Arquivo Palmela, ibidem, fl. 77; mf. 5504.

${ }^{21}$ D. Fernando de Saxe Coburgo-Gotha: Comemoração do $1^{\circ}$ Centenário da Morte do Rei -Artista. Sintra, Palácio Nacional da Pena, 1985, p. 176.

${ }^{22}$ Armazéns Grandela (...), op. cit., p. 47.

${ }^{23}$ Jornal de Horticultura Prática, 1876, p. 91.

${ }^{24}$ Ibidem, 1883, pp. 230-231.

${ }^{25}$ Convocamos o conceito de "interior autêntico", definido por Celina Bastos e Anísio Franco: "implica a preservação de todo o programa decorativo subjacente à criação de determinado espaço.", ver BASTOS, Celina e FRANCO, Anísio, "Interiores Autênticos nos Grandes Palácios em finais da Monarquia", Matrizes da Investigação em Artes Decorativas V, op. cit., pp. 147-174.

${ }^{26}$ Maria Manuela d'Oliveira Martins; Cristina Neiva Correia, "Jardim de Inverno” in Ecos de Belém, Abril/95, p. 6.

${ }^{27}$ Jornal de Horticultura Prática, 1872, p. 77.

${ }^{28}$ Ibidem, 1882, pp. 24-25. 
${ }^{29}$ Jornal de Horticultura Prática, 1882, p. 179.

${ }^{30}$ Como a Fábrica Inglesa de Móveis de Madeira, fundada por H. Drummond Castle em 1891; ver Pedro Bebiano Braga, op. cit., p. 196.

${ }^{31}$ Ver António Novaes, 1903-1911. Lisboa, AFML, 1996, ANV544.

${ }^{32}$ Ver ALÍPIO, Elsa Santos, "O Palácio da Cidadela de Cascais: História de uma Residência Oficial à BeiraMar”, Palácio da Cidadela de Cascais. Lisboa, Museu da Presidência da República, 2011, p. 136.

${ }^{33}$ Jornal de Horticultura Prática, 1880, p. 227.

${ }^{34}$ Armazéns Grandela (...), op. cit., p. 49.

35 Ibidem, p. 57.

${ }^{36}$ Ramalho Ortigão, Arte Portuguesa. Lisboa, 1943, Livraria Clássica, vol. I, p. 278. Texto publicado pela primeira vez em 1889.

${ }^{37}$ Jornal de Horticultura Prática, 1872, pp. 126-128.

38 A jardineira que se conserva no Jardim de Inverno do Palácio da Ajuda, forrada a placas cerâmicas, aproximar-se-ia, sem pés, a um daqueles modelos para o peitoril das janelas.

${ }^{39}$ Ibidem., pp. 126-127.

${ }^{40}$ Isabel, Condessa de Rio de Maior: correspondência para seus filhos 1852/1865. Estudo biográfico, org. e notas de Maria Filomena Mónica. Lisboa, Quetzal Editores, 2004, p. 304.

${ }^{41}$ Idem, ibidem, p. 321.

${ }^{42}$ Arquivos Nacionais/Torre do Tombo, Arquivo Palmela, Livro de Receita e Despesa, $\mathrm{n}^{\circ}$ 1, 1855, fls. 19, 24, 29; 1856, fl. 46; 1857, fl. 65, mf. 5504; Livro 27, 1859, fl. 5; 1861, fl. 84, mf. 5505.

${ }^{43}$ A primeira edição data de 1888; ver QUEIRÓs, Eça de, Os Maias: Episódios da Vida Romântica, Porto, Livr. Chardron, Casa Editora Lugan \& Genelioux Sucessores, 1888, 2 vols.

${ }^{44}$ QUEIRÓS, Eça de, Os Maias: Episódios da Vida Romântica, Lisboa, Livros do Brasil, [1992], p. 48.

${ }^{45}$ Idem, ibidem, p. 192.

${ }^{46}$ Idem, ibidem, p. 99.

${ }^{47}$ Idem, ibidem.

${ }^{48}$ Como refere exaustivamente Celina Bastos em "A Família Dejante: a marcenaria e a indústria dos mármores no Portugal de Oitocentos" in Revista de Artes Decorativas, dir. Gonçalo Vasconcelos e Sousa, Porto, Universidade Católica Editora/CITAR, 2009, nº 3, pp. 157-191.

${ }^{49}$ Arquivos Nacionais/Torre do Tombo, Arquivo Palmela, Livro de Receita e Despesa, $\mathrm{n}^{\circ}$ 1, 1856, fl. 54, mf. 5504.

${ }^{50}$ Jornal de Horticultura Prática, 1873, p. 53.

${ }^{51}$ Ibidem, 1887, p. 95.

52 Ibidem, 1882, p. 195.

${ }^{53}$ A primeira edição data de 1878; ver QUEIRÓS, Eça de, O Primo Basílio: Episódio Doméstico, Porto, segunda edição revista, Livraria Internacional de Ernesto Chardron, 1878.

${ }^{54}$ Referido por Pedro Bebiano Braga, op. cit., p. 190.

${ }^{55}$ Idem, ibidem, pp. 186-187. 